Cover photograph. Main-channel spans of structure A-1700 on Interstate 155 over the Mississippi River near Caruthersville, Missouri, as viewed from the downstream left (southeast) bank looking toward the upstream right (northwest) bank on January 23, 2007. 


\section{Two-Dimensional Simulation of Flow and Evaluation of Bridge Scour at Structure A-1700 on Interstate 155 over the Mississippi River near Caruthersville, Missouri}

By Richard J. Huizinga

Prepared in cooperation with the Missouri Department of Transportation

Scientific Investigations Report 2007-5230 


\section{U.S. Department of the Interior DIRK KEMPTHORNE, Secretary}

\section{U.S. Geological Survey \\ Mark D. Myers, Director}

\section{U.S. Geological Survey, Reston, Virginia: 2007}

For product and ordering information:

World Wide Web: http://www.usgs.gov/pubprod

Telephone: 1-888-ASK-USGS

For more information on the USGS--the Federal source for science about the Earth, its natural and living resources, natural hazards, and the environment:

World Wide Web: http://www.usgs.gov

Telephone: 1-888-ASK-USGS

Any use of trade, product, or firm names is for descriptive purposes only and does not imply endorsement by the U.S. Government.

Although this report is in the public domain, permission must be secured from the individual copyright owners to reproduce any copyrighted materials contained within this report.

Suggested citation:

Huizinga, R.J., 2007, Two-dimensional simulation of flow and evaluation of bridge scour at structure A-1700 on Interstate 155 over the Mississippi River near Caruthersville, Missouri: U.S. Geological Survey Scientific Investigations Report 2007-5230, 33 p. 


\section{Contents}

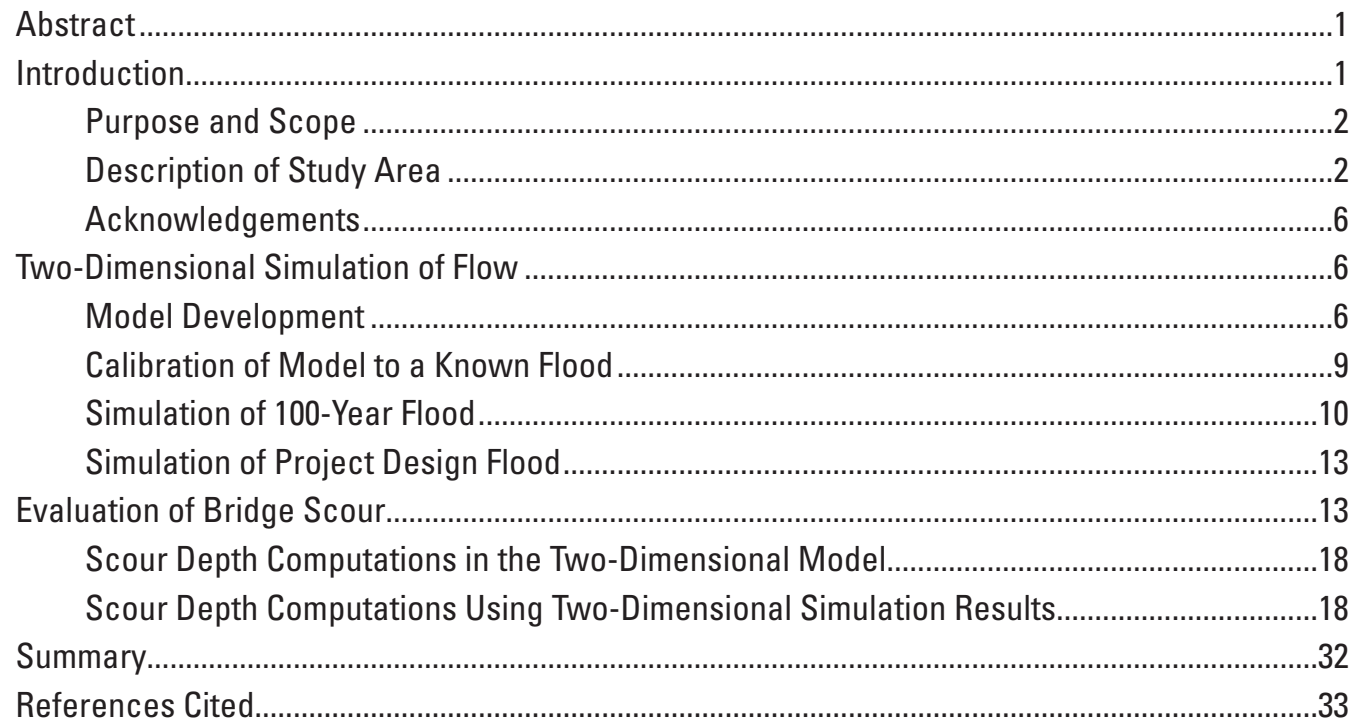

\section{Figures}

1. Photograph showing main-channel spans of structure A-1700 on Interstate 155 over the Mississippi River near Caruthersville, Missouri, as viewed from the upstream left (northeast) bank facing downstream (southwest) on January 23, 2007.....2

2. Map showing location of the study area on the Mississippi River near

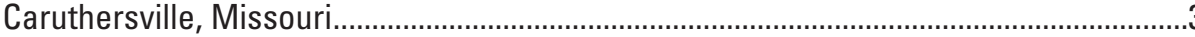

3. Aerial photograph showing study area on the Mississippi River near Caruthersville, Missouri

4. Graph showing cross section, substructural and superstructural details, and key features of structure A-1700 over the Mississippi River near Caruthersville, Missouri.

5. Map showing finite-element mesh used in flow simulations on the Mississippi River near Caruthersville, Missouri

6. Aerial photograph showing land-surface elevations from the model of the Mississippi River near Caruthersville, Missouri.

7. Map showing land-use coverages used in flow simulations on the Mississippi River near Caruthersville, Missouri

8-11. Aerial photographs showing-

8. Measured, estimated, and simulated water-surface elevations for the calibration flood of April 4, 1975, on the Mississippi River near Caruthersville, Missouri.

9. Rated and simulated water-surface elevations for the 100 -year flood on the Mississippi River near Caruthersville, Missouri

10. Rated and simulated water-surface elevations for the project design flood on the Mississippi River near Caruthersville, Missouri.

11. Simulated depths and velocity vectors in the vicinity of structure A-1700 for the project design flood on the Mississippi River near Caruthersville, Missouri. 
12. Aerial photograph showing simulated velocity magnitudes for project design flood and flux lines used for scour parameter determinations on the Mississippi River near Caruthersville, Missouri

13-16. Graphs showing-

13. Predicted contraction and local pier scour depths under the Tennessee-approach (left overbank) spans for the project design flood on the Mississippi River near Caruthersville, Missouri.

14. Predicted contraction and local pier scour depths under the main-channel and Missouri-approach (right overbank) spans for the project design flood on the Mississippi River near Caruthersville, Missouri..

15. Predicted total scour depths under the Tennessee-approach (left overbank) spans for three floods on the Mississippi River near Caruthersville, Missouri ......29

16. Predicted total scour depths under the main-channel and Missouri-approach (right overbank) spans for three floods on the Mississippi River near Caruthersville, Missouri.

17. Photograph showing abutment and part of the guidebank upstream from the right (northwest) end of structure A-1700 over the Mississippi River near Caruthersville, Missouri, January 23, 2007

\section{Tables}

1. Material and hydraulic properties of various land-use coverages in the model of the Mississippi River near Caruthersville, Missouri, resulting from the calibration flood of April 4, 1975

2. Measured and simulated water-surface elevations for the calibration flood of April 4, 1975, on the Mississippi River near Caruthersville, Missouri.

3. Predicted live-bed contraction scour depths and parameters used to compute main-channel contraction scour on the Mississippi River near Caruthersville, Missouri.

4. Predicted clear-water contraction scour depths and parameters used to compute overbank contraction scour on the Mississippi River near Caruthersville, Missouri....20

5. Predicted local pier scour depths and parameters used to compute pier scour for the calibration flood of April 4, 1975, on the Mississippi River near Caruthersville, Missouri.

6. Predicted local pier scour depths and parameters used to compute pier scour for the 100-year flood on the Mississippi River near Caruthersville, Missouri

7. Predicted local pier scour depths and parameters used to compute pier scour for the project design flood on the Mississippi River near Caruthersville, Missouri.....

8. Predicted abutment scour depths and parameters used to compute abutment scour on the Mississippi River near Caruthersville, Missouri 


\section{Conversion Factors and Datum}

\begin{tabular}{|c|c|c|}
\hline Multiply & By & To obtain \\
\hline \multicolumn{3}{|c|}{ Length } \\
\hline inch (in.) & 2.54 & centimeter $(\mathrm{cm})$ \\
\hline inch (in.) & 25.4 & millimeter $(\mathrm{mm})$ \\
\hline foot $(\mathrm{ft})$ & 0.3048 & meter $(\mathrm{m})$ \\
\hline mile (mi) & 1.609 & kilometer $(\mathrm{km})$ \\
\hline \multicolumn{3}{|c|}{ Area } \\
\hline acre & 4,047 & square meter $\left(\mathrm{m}^{2}\right)$ \\
\hline acre & 0.4047 & hectare (ha) \\
\hline acre & 0.004047 & square kilometer $\left(\mathrm{km}^{2}\right)$ \\
\hline square foot $\left(\mathrm{ft}^{2}\right)$ & 0.09290 & square meter $\left(\mathrm{m}^{2}\right)$ \\
\hline square mile $\left(\mathrm{mi}^{2}\right)$ & 2.590 & square kilometer $\left(\mathrm{km}^{2}\right)$ \\
\hline \multicolumn{3}{|c|}{ Flow rate } \\
\hline foot per second $(\mathrm{ft} / \mathrm{s})$ & 0.3048 & meter per second $(\mathrm{m} / \mathrm{s})$ \\
\hline cubic foot per second $\left(\mathrm{ft}^{3} / \mathrm{s}\right)$ & 0.02832 & cubic meter per second $\left(\mathrm{m}^{3} / \mathrm{s}\right)$ \\
\hline \multicolumn{3}{|c|}{ Hydraulic gradient } \\
\hline foot per mile (ft/mi) & 0.1894 & meter per kilometer $(\mathrm{m} / \mathrm{km})$ \\
\hline \multicolumn{3}{|c|}{ Kinematic viscosity } \\
\hline square foot per second $\left(\mathrm{ft}^{2} / \mathrm{s}\right)$ & 0.09290 & square meter per second $\left(\mathrm{m}^{2} / \mathrm{s}\right)$ \\
\hline \multicolumn{3}{|c|}{ Unit discharge $^{*}$} \\
\hline $\begin{array}{l}\text { cubic foot per second per foot } \\
{\left[\left(\mathrm{ft}^{3} / \mathrm{s}\right) / \mathrm{ft}\right]}\end{array}$ & 0.09290 & $\begin{array}{l}\text { cubic meter per second per meter } \\
{\left[\left(\mathrm{m}^{3} / \mathrm{s}\right) / \mathrm{m}\right]}\end{array}$ \\
\hline
\end{tabular}

Vertical coordinate information is referenced to the National Geodetic Vertical Datum of 1929 (NGVD 29).

Horizontal coordinate information is referenced to the North American Datum of 1983 (NAD 83).

*Unit discharge: The standard unit for unit discharge is cubic foot per second per foot [(ft3 $3 / \mathrm{s}) /$ $\mathrm{ft}]$. In this report, the mathematically reduced form, square foot per second $\left(\mathrm{ft}^{2} / \mathrm{s}\right)$, is used for convenience.

In this report, the words "left" and "right" generally refer to directions that would be reported by an observer facing downstream. 



\title{
Two-Dimensional Simulation of Flow and Evaluation of Bridge Scour at Structure A-1700 on Interstate 155 over the Mississippi River near Caruthersville, Missouri
}

\author{
By Richard J. Huizinga
}

\section{Abstract}

The evaluation of scour at bridges throughout the State of Missouri has been ongoing since 1991, and most of these evaluations have used one-dimensional hydraulic analysis and application of conventional scour depth prediction equations. Occasionally, the complex conditions of a site dictate a more thorough assessment of the stream hydraulics beyond a onedimensional model. This was the case for structure A-1700, the Interstate 155 bridge crossing the Mississippi River near Caruthersville, Missouri. To assess the complex hydraulics at this site, a two-dimensional hydrodynamic flow model was used to simulate flow conditions on the Mississippi River in the vicinity of the Interstate 155 structure A-1700. The model was used to simulate flow conditions for three discharges: a flood that occurred on April 4, 1975 (the calibration flood), which had a discharge of 1,658,000 cubic feet per second; the 100 -year flood, which has a discharge of 1,960,000 cubic feet per second; and the project design flood, which has a discharge of 1,974,000 cubic feet per second. The project design flood was essentially equivalent to the flood that would cause impending overtopping of the mainline levees along the Mississippi River in the vicinity of structure A-1700. Discharge and river-stage readings from the flood of April 4, 1975, were used to calibrate the flow model. The model was then used to simulate the 100-year and project design floods.

Hydraulic flow parameters obtained from the three flow simulations were applied to scour depth prediction equations to determine contraction, local pier, and abutment scour depths at structure A-1700. Contraction scour and local pier scour depths computed for the project design discharge generally were the greatest, whereas the depths computed for the calibration flood were the least. The maximum predicted total scour depth (contraction and local pier scour) for the calibration flood was 66.1 feet; for the 100-year flood, the maximum predicted total scour depth was 74.6 feet; for the project design flood, the maximum predicted total scour depth was 93.0 feet. If scour protection did not exist, bent 14 and piers 15 through 21 would be substantially exposed or undermined by the predicted total scour depths in all of the flood simulations.
However, piers 18 through 21 have a riprap blanket around the base of each, and the riprap blanket observed on the right bank around bent 14 is thought to extend around the base of pier 15 , which would limit the amount of scour that would occur at these piers. Furthermore, the footings and caissons that are not exposed by computed contraction scour may arrest local pier scour, which will limit local pier scour at several bents and piers. Nevertheless, main-channel piers 16 and 17 and all of the bents on the left (as viewed facing downstream) overbank are moderately to substantially exposed by the predicted scour depths from the three flood simulations, and there is no known scour protection at these piers or bents. Abutment scour depths were computed for structure A-1700, but abutment scour is expected to be mitigated by the presence of guidebanks upstream from the bridge abutments, as well as riprap revetment on the abutment and guidebank faces.

\section{Introduction}

In 1988, the Federal Highway Administration (FHWA) recommended that "every bridge over a scourable stream, whether existing or under design, should be evaluated as to its vulnerability to floods in order to determine the prudent measures to be taken for its protection" (U.S. Federal Highway Administration, 1988). In 1991, the U.S. Geological Survey (USGS) and the Missouri Department of Transportation (MoDOT) began a cooperative study to accomplish two goals: (1) to develop and use a suitable screening process to identify "scour-susceptible" bridges, and (2) for bridges identified as "scour-susceptible," perform a detailed hydraulic evaluation and estimate values of scour using accepted hydraulic techniques. The term "scour-susceptible" describes a bridge that is deemed potentially unstable because abutment or pier foundations have the potential to be undermined by erosion of the channel bed or banks (U.S. Federal Highway Administration, 1988). Nearly 3,100 bridges throughout Missouri were screened for scour-susceptibility, and nearly 400 bridges have undergone a detailed hydraulic evaluation and estimation of scour depths (Huizinga and Rydlund, 2004). 
The detailed hydraulic evaluations have been performed using techniques outlined in Hydraulic Engineering Circular No. 18 (Richardson and Davis, 2001), which generally entails the application of predictive scour-depth computations using parameters from a one-dimensional hydraulic analysis. Occasionally, however, the simplifying assumptions that must be made to apply a one-dimensional hydraulic analysis to a two-dimensional flow scenario are deemed unreasonable. This is the case at structure A-1700 on Interstate 155 over the Mississippi River near Caruthersville, Missouri (hereinafter referred to as "structure A-1700"; fig. 1). The Mississippi River meanders in the immediate vicinity of structure A-1700, with associated bends in the mainline levees on the adjacent flood plains. Rock dikes built and maintained by the U.S. Army Corps of Engineers (USACE) in the bend upstream from structure A-1700 further contribute to the two- and threedimensional nature of the flow around structure A-1700. This unique configuration is beyond the reasonable bounds for a one-dimensional hydraulic analysis, indicating the need for a two-dimensional hydraulic analysis of the site.

\section{Purpose and Scope}

This report describes the two-dimensional simulation of flow and evaluation of bridge scour at structure A-1700. The report contains the description of the development of and results from a two-dimensional hydrodynamic flow model that represents part of the Mississippi River at Interstate 155 near Caruthersville, Mo., using the depth-averaged flow model Flo2DH [part of the Federal Highway Administration's Finite Element Surface-Water Modeling System (FESWMS) designed for hydraulic structures and flood plains (Froehlich, 2002)]. The model was calibrated to the flood of April 4, 1975 , and used to simulate the 100 -year recurrence flood as well as the project design flood (PDF), which is the flood that causes impendent overtopping of the USACE mainline levees at some point in the stretch of river between Hickman, Ky., and Memphis, Tenn. (Barry Bruchman, U.S. Army Corps of Engineers, oral commun., 2007). The model was used to com- pute the hydraulic parameters needed to determine the contraction scour, local pier scour, and abutment scour that might occur at structure A-1700 for the three flood discharges.

\section{Description of Study Area}

The study area is located along the eastern edge of Pemiscot County, and covers part of the Mississippi River and associated flood plains between the USACE mainline levees upstream and downstream from Interstate 155 near Caruthersville (figs. 2 and 3). The study area begins at river mile (mi) 832.5, near a local constriction in the mainline levees at Cottonwood Point, Mo., and ends at river mi 846.8, near the upstream edge of Caruthersville. In addition to Pemiscot County in Missouri, the study area also covers parts of Lake and Dyer Counties in Tennessee, and includes such features as the Towhead of Island No. 18, Blaker Towhead, and the Linwood Bend (U.S. Army Corps of Engineers, 2007a; figs. 2 and 3). Numerous rock dikes and other revetments are present along the banks of the river in the study area.

In the vicinity of the study area, the dominant physiographic feature is the Mississippi Alluvial Plain, which is approximately $70 \mathrm{mi}$ wide measured in a west-northwest direction from the eastern bluffs at Lenox, Tenn., (about $7 \mathrm{mi}$ west of Dyersburg, Tenn.) to the western bluffs at Harviell, Mo., (about $7.5 \mathrm{mi}$ southwest of Poplar Bluff, Mo.). To control flooding over this vast area of minimal relief, the USACE built and maintains mainline levees along both sides of the Mississippi River. For the downstream part of the study area, these mainline levees are about 2.8 to $3.5 \mathrm{mi}$ apart, but flare out to nearly $7 \mathrm{mi}$ apart in the upstream part of the study area because of a large meander bend in the river (fig. 2).

Interstate 155 crosses the Mississippi River from northwest to southwest at about river mi 839.0, at the approximate midpoint of the study area. Structure A-1700 is a 7,100-foot (ft) long bridge, with the main spans consisting of a 1,440-ft cantilevered through-truss span, eight 235 -ft steel I-beam spans, and two 132-ft steel I-beam spans with concrete piers founded on caissons and piles (fig. 4). The Tennessee-ap-

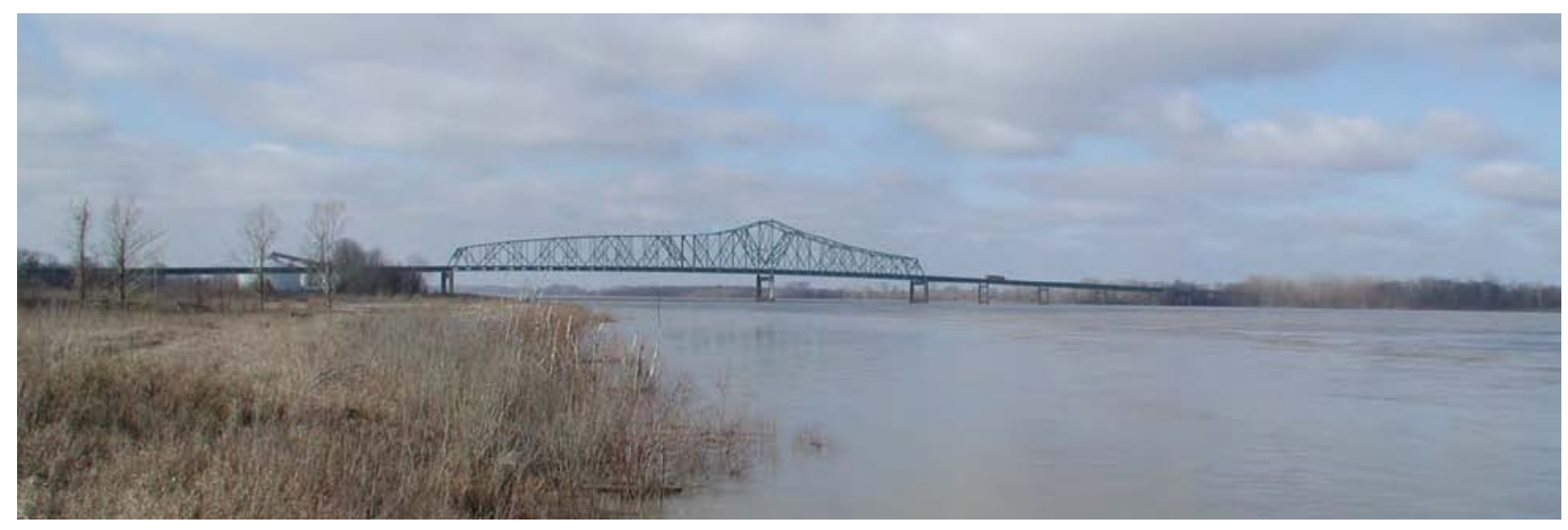

Figure 1. Main-channel spans of structure A-1700 on Interstate 155 over the Mississippi River near Caruthersville, Missouri, as viewed from the upstream left (northeast) bank facing downstream (southwest) on January 23, 2007. 


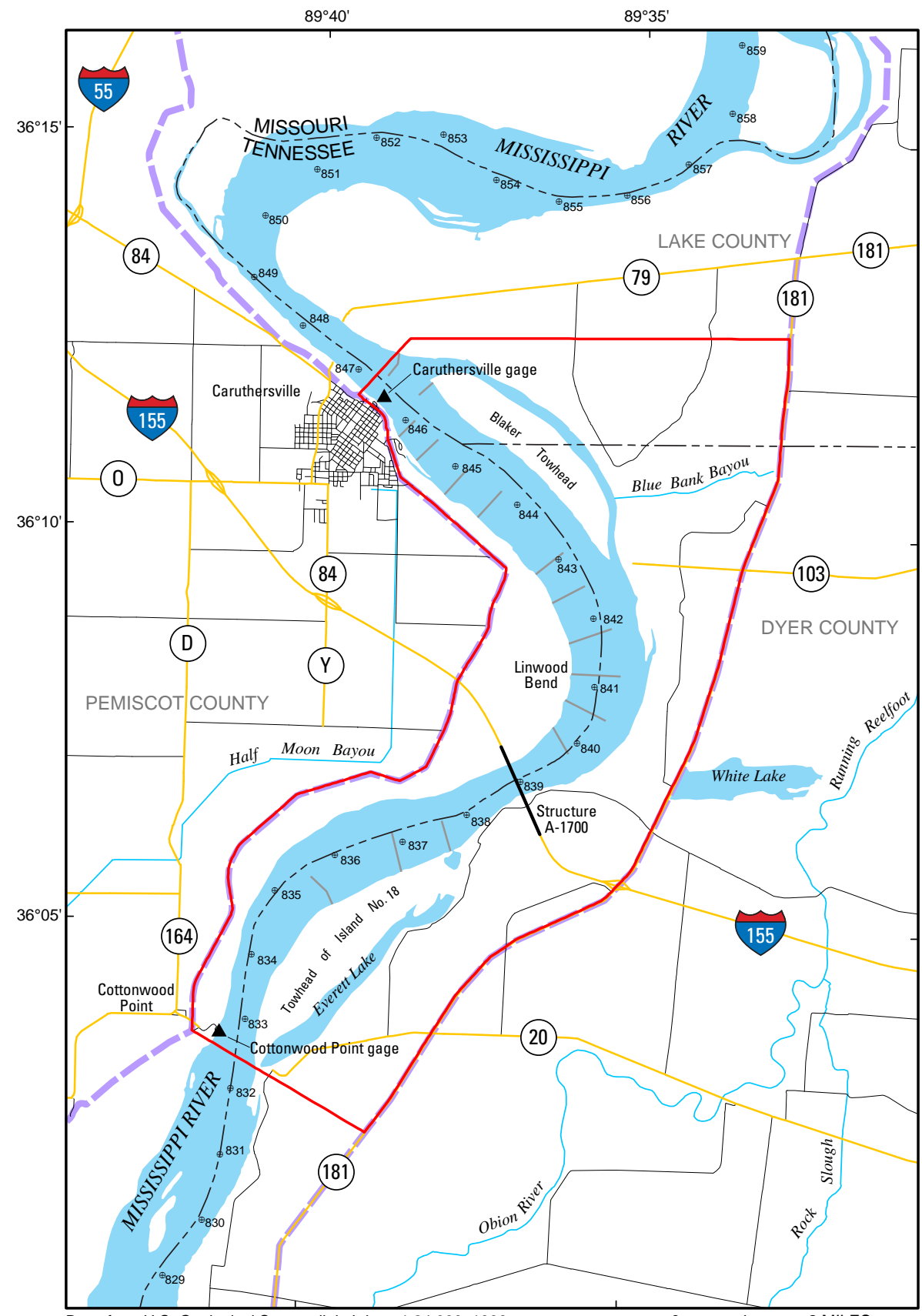

Base from U.S. Geological Survey digital data, 1:24,000, 1996 Universal Transverse Mercator projection, Zone 16

Horizontal coordinate information referenced to the North American

Datum of 1983 (NAD 83)

EXPLANATION

Boundary of study area

Primary highway

Minor roadway

Mainline levee

Rock dike (within study area)

$\oplus_{841} \quad$ River-mile marker-Number is distance upstream from Gulf of Mexico

$\Delta \quad$ U.S. Army Corps of Engineers river stage gaging station

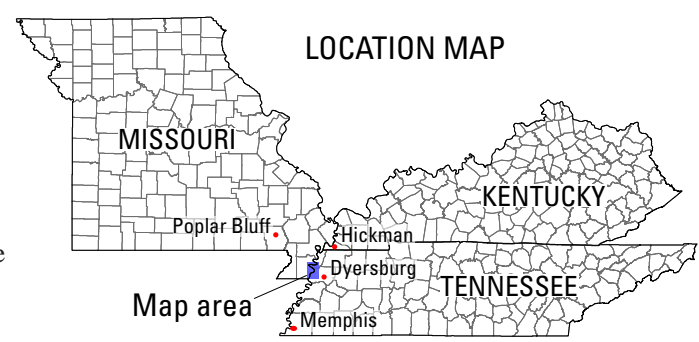

Figure 2. Location of the study area on the Mississippi River near Caruthersville, Missouri. 


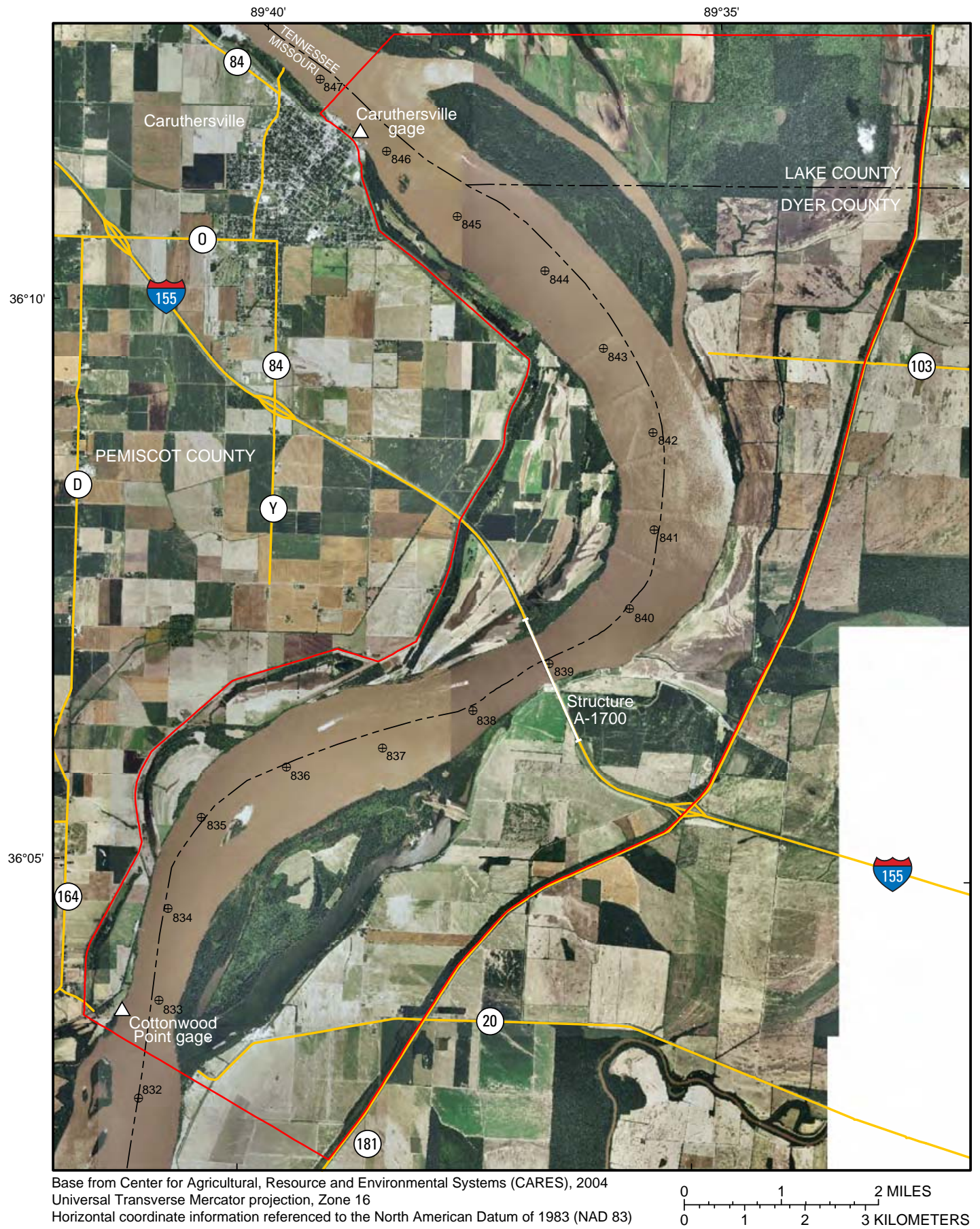

EXPLANATION
— Study area boundary
_ Primary highways
$\oplus_{841} \quad$ River-mile marker- Number is distance upstream from
Gulf of Mexico
$\triangle$ U.S. Army Corps of E ngineers river stage gaging station

Figure 3. Study area on the Mississippi River near Caruthersville, Missouri. 


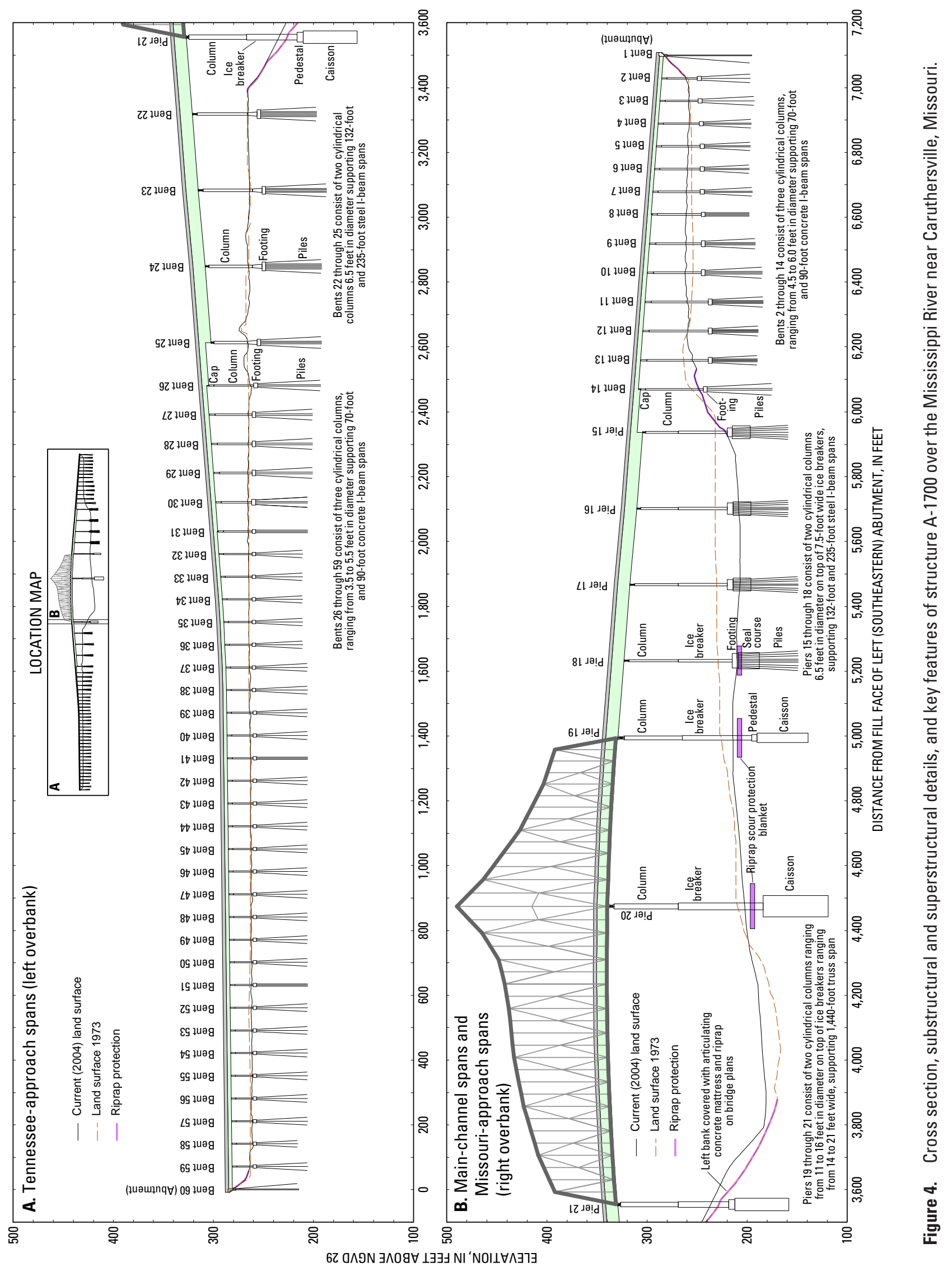


proach spans on the eastern side consist of twenty-nine $70-\mathrm{ft}$ and five $90-\mathrm{ft}$ concrete I-beam spans on concrete bents with pile foundations. The Missouri-approach spans on the western side consist of seven 70 -ft long and six 90 -ft long concrete I-beam spans on concrete bents with pile foundations. Both abutment faces are covered with large cobble riprap, and there are riprap-covered guidebanks upstream from both abutments. Elevated, level road embankments extend to the mainline levees from both of the approach spans of structure A-1700. Both road embankments curve gently to the left as they approach the mainline levees from the bridge (figs. 2 and 3), and descend to an elevation about $3 \mathrm{ft}$ above the surrounding flood plain outside of the confines of the mainline levees.

In the study area, the flood plain predominantly consists of agricultural land used for growing cotton and corn, with areas of timber and brush (fig. 3). A thick riparian corridor is present along the Mississippi River, and wetland areas with surrounding timber border the mainline levees and various minor levees throughout the study area. The Towhead of Island No. 18 and Blaker Towhead are covered with timber and brush.

\section{Acknowledgements}

The author appreciates the assistance of two individuals with the U.S. Army Corps of Engineers, Memphis District. Barry Bruchman provided information about various historic floods that have occurred on the Mississippi River, along with information from the stage gage at Caruthersville, Missouri. Derrick Smith provided detailed elevation data for the flood plain in the vicinity of Interstate 155, recent hydrographic surveys of the channel, and information about the rock dikes built in the channel bend upstream from Interstate 155.

\section{Two-Dimensional Simulation of Flow}

The FESWMS Flo2DH model simulates flow in two dimensions in the horizontal plane. It uses a finite-element mesh and the Galerkin finite-element method of solving three partial-differential equations representing conservation of mass and momentum (Froehlich, 2002). This two-dimensional model can simulate longitudinal and lateral variations in water-surface elevations and velocities and can accommodate geometric features such as highway embankments, bridge structures, channel bends, berms, buildings, and other flow obstructions. A graphic user interface called the Surface-Water Modeling System (SMS; Environmental Modeling Research Laboratory, 1999) was used to construct the two-dimensional finite-element mesh, facilitate assignment of roughness coefficients and other hydraulic and material parameters to the mesh elements, execute the model, and evaluate the model output numerically and graphically.

\section{Model Development}

The extent of the model mesh was from a point of constriction in the mainline levees near Cottonwood Point, at river mi 832.5 to the upstream (north) edge of Caruthersville, at river mi 846.8 (figs. 2 and 3). The model mesh extended from Tennessee Highway 181 along the mainline levee on the left (east) flood plain, to the mainline levee on the right (west) flood plain (figs. 2 and 3).

Ground-elevation information for the study area was provided by the USACE (Derrick Smith, U.S. Army Corps of Engineers, written commun., 2007) as a combination of Light Detection and Ranging (LiDAR) data for the flood plains and bathymetric data from a recent hydrographic survey for the channel. These data formed the base topographic data for the model.

Mesh elements were designed with consideration to computational speed and the level of detail of the hydraulic information required from the simulation results (fig. 5). The area around structure A-1700 and the approach road embankments were of critical interest, so smaller elements were used in this part of the study area, whereas larger elements were used to represent the channel and flood plains toward the upstream and downstream ends of the study area (fig. 5). Secondary levees (such as the Boothspoint and Tennemo levees; fig 6) and older levees within the confines of the mainline levees were included with a moderate amount of detail to represent these local features more accurately (fig. 6). Elevation data were available for most of the dikes along the right (west) bank in the Linwood Bend upstream from structure A-1700 (Derrick Smith, written commun., 2007), and these dikes were included with a moderate amount of detail to improve the simulation of flow near these features (fig. 6). Other dikes were present upstream and downstream from the Linwood Bend dikes, but elevation data for several of these dikes were not readily available (Derrick Smith, written commun., 2007), or the elevation of the channel bed near the dike essentially was the same as the elevation of the dike, so that the dike would not substantially affect flow. Specific elevation details from these dikes generally were not included in the mesh; therefore, these dikes do not appear in figure 6 .

Piers and bents for structure A-1700 were incorporated into the model mesh using the pier module in Flo2DH. Position, orientation, and dimensions of each pier and bent were obtained from bridge plans (Missouri Department of Transportation, 1974) to accurately position and size the piers and bents. All piers and bents were coded based on their cross section at the interface with the current (2004) land surface on the bridge plans. Typically, piers were coded as solid, round-nosed columns with a width and length equal to the overall width and length from the bridge plans. To be consistent with guidelines for the computation of pier scour in Richardson and Davis (2001), bents with multiple columns spaced less than 5 times the column diameter apart were analyzed as a round-nosed column with a width equal to a single column and a length equal to the number of columns multiplied by the width of a 


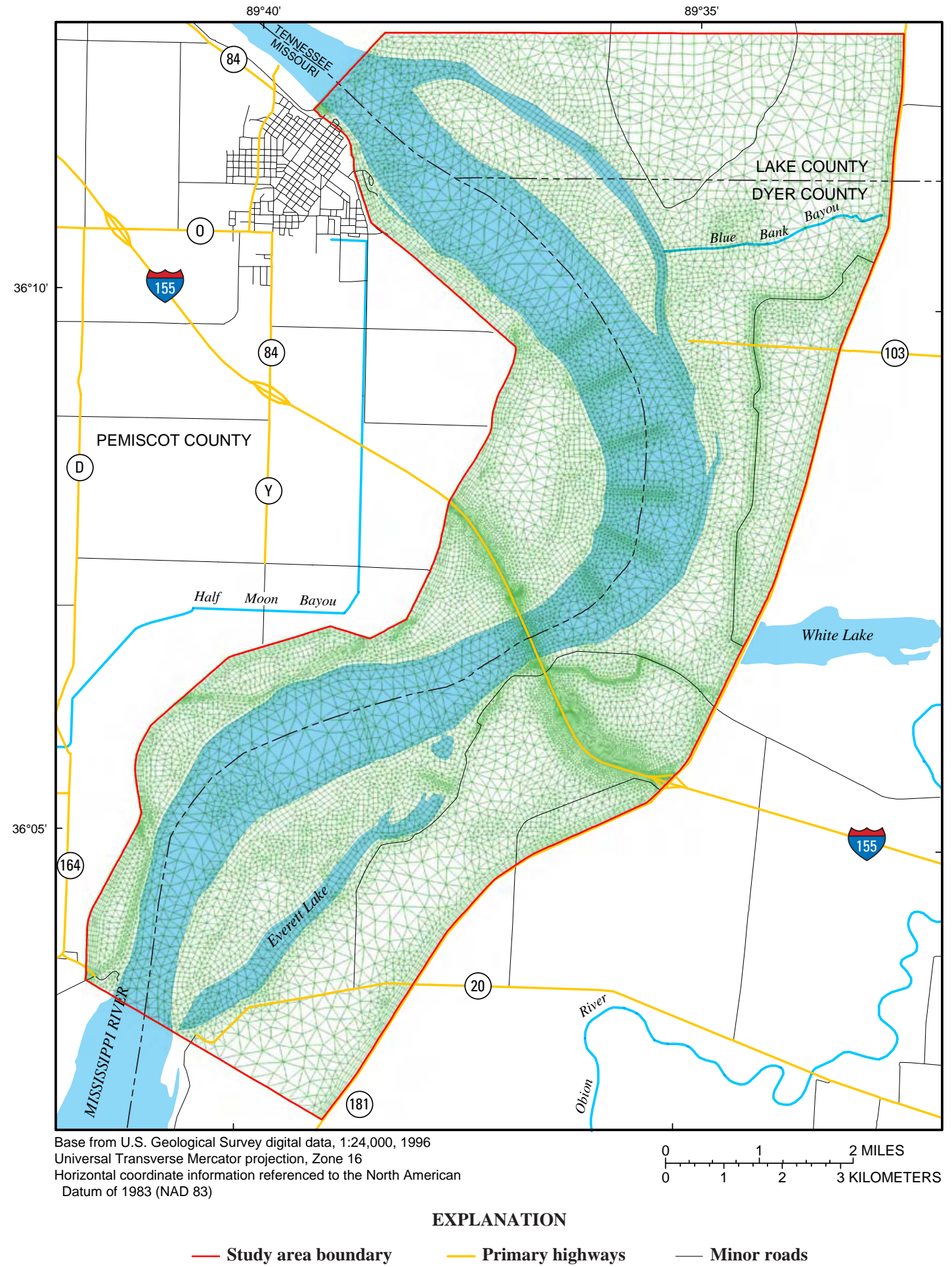

Figure 5. Finite-element mesh used in flow simulations on the Mississippi River near Caruthersville, Missouri. 


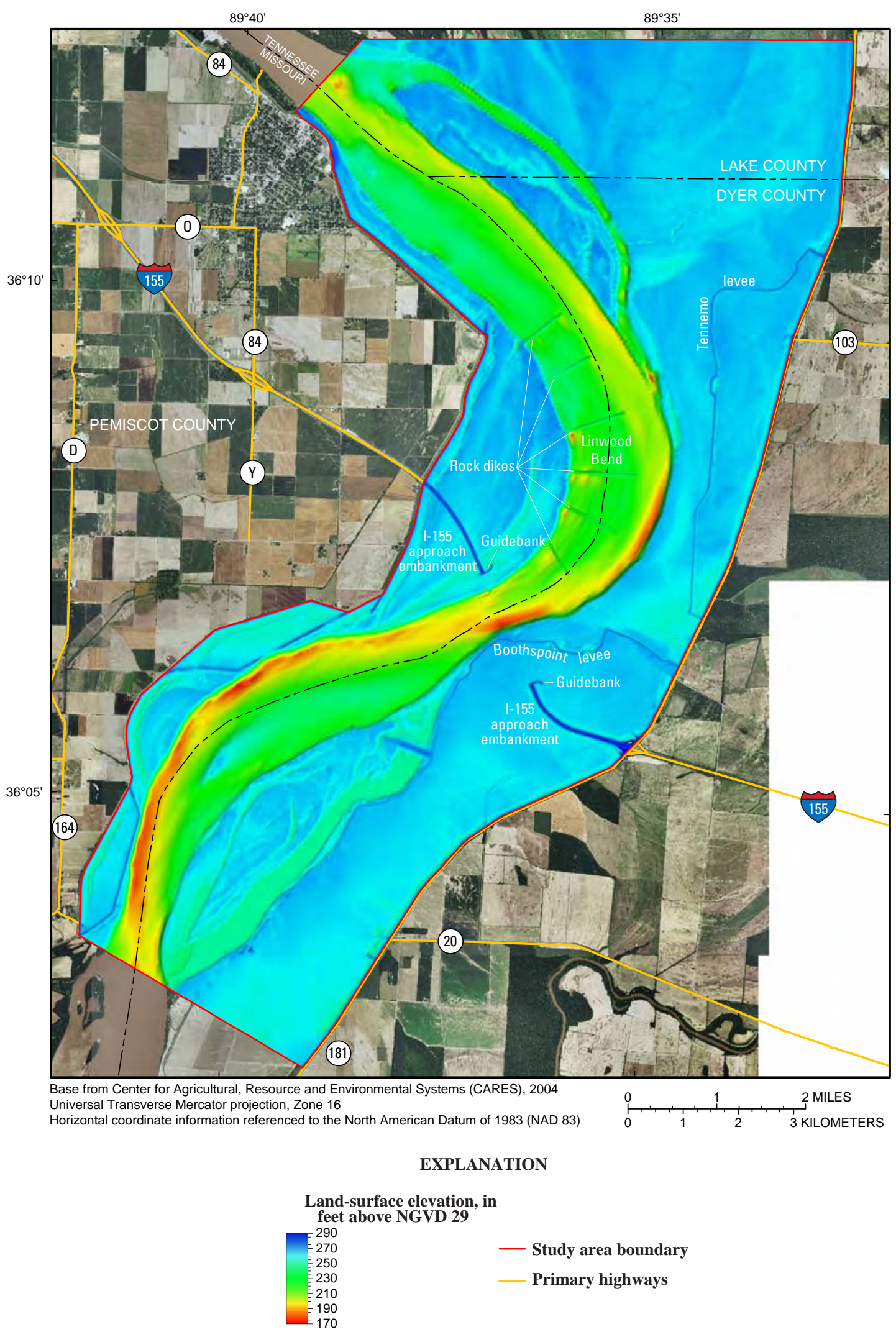

Figure 6. Land-surface elevations from the model of the Mississippi River near Caruthersville, Missouri. 
single column, whereas bents with multiple columns spaced more than 5 times the column diameter apart were coded as a single cylindrical column with a width and length equal to the diameter of a single column.

The finite-element mesh consisted of 25,550 elements that ranged in size from 522 square feet $\left(\mathrm{ft}^{2}\right)$ to 13.86 acres. Each element had a node at each corner and at the midpoint of each side, which created a total of 58,833 nodes.

\section{Calibration of Model to a Known Flood}

The model was calibrated to the flood that occurred on the Mississippi River in April 1975. Based on information provided by the USACE (Barry Bruchman, oral commun., 2007; U.S. Army Corps of Engineers, 2007b), the gage heights recorded on April 4, 1975, at the USACE stage-gaging stations at Caruthersville (river mi 846.4; hereinafter referred to as "the Caruthersville gage") and Cottonwood Point (river mi 832.7; hereinafter referred to as "the Cottonwood Point gage") were $277.89 \mathrm{ft}$ and $270.08 \mathrm{ft}$, and the discharge computed at Hickman, Ky. (the nearest discharge station upstream from Caruthersville, at river mi 921.4), was 1,658,000 cubic feet per second $\left(\mathrm{ft}^{3} / \mathrm{s}\right)$. No major inflow tributaries to the Mississippi River exist between Hickman and Cottonwood Point, and no substantial flood storage or attenuation occurs on this reach according to the USACE; therefore, the peak discharge measured at Hickman can be associated with the peak stages measured at Caruthersville and Cottonwood Point (Barry Bruchman, oral commun., 2007). The water-surface elevation at structure A-1700 was estimated as $273.67 \mathrm{ft}$ using the average slope of the water surface between the Caruthersville and Cottonwood Point gages for the flood, which was approximately 0.57 feet per mile (ft/mi).

The simulation of a particular flow scenario with Flo2DH requires an iterative process called spindown (Huizinga, 2007; Huizinga and Rydlund, 2001). In a subcritical flow regime (deep, slow flow typical of non-alpine streams and rivers), spindown involves initializing the model with the desired discharge as the upstream boundary condition and a downstream water-surface elevation that is higher than the highest land-surface elevation in the mesh. This ensures that all nodes in the model are "wet" (having a positive depth of flow) and produces a flat water-surface elevation across the model grid, which promotes numerical stability for the initial model computations. The model is run with these conditions for a sufficient number of iterations to cause the water-surface elevation changes between iterations to be minimized within a preset limit. Once the limit is reached, the model is said to have "converged." The downstream water-surface elevation is then decreased by some finite amount, the model is restarted using the results of the previous run-called a hotstart-as the starting point for the new run, and the model is run until convergence occurs. This process is repeated until the desired downstream water-surface elevation is reached, as dictated by high-water marks, flood profiles, or other known site param- eters. During the spindown process, if the simulated water-surface elevation at a particular node is less than the land-surface elevation assigned to the node, then the node is said to "go dry." If one or more of the nodes for a particular element go dry, then the element goes dry, and the element is not included in the computations during that iteration. As the simulation proceeds through iterations, an element can oscillate between wet and dry, which can lead to solution instability and a loss of convergence. To limit this instability, the user sets a tolerance on the depth of flow over a node (the storativity depth, table 1); however, if an element goes dry and stays dry for several iterations, it can and should be manually disabled to prevent model instability. Once the spindown process is complete, the model calibration can be refined by adjusting other model parameters such as Manning's roughness coefficient and kinematic eddy viscosity.

For the current model, the upstream boundary was set to the flood discharge of $1,658,000 \mathrm{ft}^{3} / \mathrm{s}$ and the downstream boundary initially was set to $306.0 \mathrm{ft}$. The model then was spun down to a downstream boundary condition of $270.0 \mathrm{ft}$, which was the estimated water-surface elevation based on the water-surface slope of $0.57 \mathrm{ft} / \mathrm{mi}$ between the Caruthersville and the Cottonwood Point gages.

Material and hydraulic properties were assigned to the model based on land use from aerial photography (fig. 7), and initial Manning's roughness coefficients were assigned based on published guidance (Chow, 1959; Barnes, 1967; Arcement and Schneider, 1989) and previously calibrated models of similar river reaches (Huizinga and Rydlund, 2001). A depthdependent Manning's roughness coefficient ( $n$-value) method was used, wherein the "lower depth" $n$-value is applied when the water depth over the nodes around an element is less than the lower depth, and the "upper depth" $n$-value is applied when the water depth is greater than the upper depth; when the water depth is between the lower and upper depths, the $n$-value is interpolated linearly from the upper and lower $n$-values (Froehlich, 2002). Depth-dependent $n$-values were used to account for changes in the roughness with increased depth of flow; generally, the roughness decreases with increased depth because the effect of the physical features causing the roughness decreases as the depth of flow increases (for example, grass and crops that lie over in high flows). In addition, all of the coverages initially were assigned a large value of kinematic eddy viscosity that would promote model stability [75 square feet per second $\left.\left(\mathrm{ft}^{2} / \mathrm{s}\right)\right]$ during the spindown process. After spinning the model down to the desired boundary conditions, the eddy viscosity was adjusted to a more appropriate value (the "Mississippi River channel" and "Riprap banks and dikes" coverages were adjusted to $30 \mathrm{ft}^{2} / \mathrm{s}$ and all other coverages were adjusted to $10 \mathrm{ft}^{2} / \mathrm{s}$ ) consistent with guidelines in Froehlich (2002).

To refine the model calibration, the material properties were adjusted to the values in table 1 to cause the watersurface elevations in the model to match the observed watersurface elevations at Caruthersville and Cottonwood Point from the April 1975 flood. Matching the observed elevations 
Table 1. Material and hydraulic properties of various land-use coverages in the model of the Mississippi River near Caruthersville, Missouri, resulting from the calibration flood of April 4, 1975.

[ft, feet]

\begin{tabular}{|c|c|c|c|c|c|}
\hline \multirow[b]{2}{*}{ Land-use coverage } & \multicolumn{2}{|c|}{ Lower depth } & \multicolumn{2}{|c|}{ Upper depth } & \multirow{2}{*}{$\begin{array}{c}\text { Storativity } \\
\text { depth } \\
\text { (ft) }\end{array}$} \\
\hline & $\begin{array}{c}\text { Manning's } \\
n\end{array}$ & $\begin{array}{c}\text { Depth } \\
\text { (ft) }\end{array}$ & $\begin{array}{c}\text { Manning's } \\
n\end{array}$ & $\begin{array}{c}\text { Depth } \\
\text { (ft) }\end{array}$ & \\
\hline \multicolumn{6}{|c|}{ Channel and bank } \\
\hline Mississippi River channel & 0.035 & 15 & 0.028 & 30 & 1.0 \\
\hline Riprap banks and dikes & .100 & 5 & .043 & 30 & 2.0 \\
\hline Thick timber and thick brush & .180 & 10 & .150 & 30 & 1.5 \\
\hline Timber and brush & .150 & 10 & .120 & 25 & 1.5 \\
\hline \multicolumn{6}{|c|}{ Flood plain } \\
\hline Row crops (cotton and corn) & 0.090 & 3 & 0.060 & 20 & 1.5 \\
\hline Grassy area with interspersed trees & .050 & 1 & .040 & 3 & 1.0 \\
\hline Grassy embankment & .040 & 1 & .035 & 3 & 2.0 \\
\hline Pavement and gravel & .020 & 1 & .015 & 2 & .5 \\
\hline Thick brush (small trees and scrub) & .150 & 5 & .100 & 15 & 1.5 \\
\hline Wetlands & .065 & 10 & .040 & 25 & 3.0 \\
\hline
\end{tabular}

at the two gages was the priority in the calibration; however, an extremely close match to the estimated elevation at the bridge also was obtained. Measured and simulated watersurface elevations for the flood are shown in figure 8 and table 2.

Simulated results indicate that the maximum velocity in the main channel was 10.7 feet per second (ft/s) and occurred on the mid-left side of the main channel immediately downstream from structure A-1700. The maximum depth was 95.1 $\mathrm{ft}$ and occurred about 3 mi downstream from structure A-1700 along the right bank. The maximum depth near structure A-1700 was $92.5 \mathrm{ft}$ at the base of the left bank immediately downstream from structure A-1700. The mean water-surface elevation at structure A-1700 was $273.70 \mathrm{ft}$.

\section{Simulation of 100-Year Flood}

The 100-year flood is the discharge that has a 1 in 100 chance of occurring during any given year. It is used as a standard value in flood-plain assessment and bridge design and is a recommended event for assessing scour potential (Richardson and Davis, 2001). Therefore, the 100-year flood was simulated to provide hydraulic parameters for the computation of scour at structure A-1700.

At the Caruthersville gage, the USACE has determined the stage for the 100-year flood to be $281.80 \mathrm{ft}$ plus or minus (+/-) $0.05 \mathrm{ft}$, with a corresponding discharge of 1,960,000 $\mathrm{ft}^{3} / \mathrm{s}$; stage and discharge for the 100-year flood at the Cottonwood Point gage have not been determined (Barry Bruchman, oral commun., 2007). Consequently, the upstream boundary condition (discharge) for the 100-year flood simulation was known, but the downstream boundary condition (water-surface elevation) was not. The simulation of the 100-year flood used the material and hydraulic properties determined in the calibration simulation and a known upstream boundary discharge of $1,960,000 \mathrm{ft}^{3} / \mathrm{s}$; however, a downstream boundary condition was assumed and adjusted until the simulated water-surface elevation at the Caruthersville gage matched the known water-surface elevation of $281.80 \mathrm{ft}(+/-0.05 \mathrm{ft})$. The downstream boundary for the 100 -year flood simulation initially was spun down to $273.9 \mathrm{ft}$, using the water-surface slope from the calibration simulation $(0.57 \mathrm{ft} / \mathrm{mi})$; however, the simulated water-surface elevation at the Caruthersville gage for this downstream condition was $282.00 \mathrm{ft}$. Lowering the downstream water-surface elevation to $273.7 \mathrm{ft}$ resulted in a simulated water-surface elevation at the gage of $281.87 \mathrm{ft}$, and lowering the downstream water-surface elevation to $273.6 \mathrm{ft}$ resulted in a simulated water-surface elevation at the gage of $281.80 \mathrm{ft}$. The latter downstream condition corresponds to a water-surface slope of $0.59 \mathrm{ft} / \mathrm{mi}$, which is slightly greater than the calibration simulation slope of $0.57 \mathrm{ft} / \mathrm{mi}$, but compares favorably with it. The simulated water-surface elevations for the entire study area for the 100-year flood are shown in figure 9.

Simulated results indicate that the maximum velocity in the main channel was $11.7 \mathrm{ft} / \mathrm{s}$ and occurred on the mid-left side of the main channel immediately downstream from structure A-1700. The maximum depth was $98.4 \mathrm{ft}$ and occurred approximately 3 mi downstream from structure A-1700 along the right bank. The maximum depth near structure A-1700 was $96.1 \mathrm{ft}$ at the base of the left bank immediately downstream from structure A-1700. The average water-surface elevation at structure A-1700 was $277.42 \mathrm{ft}$. 


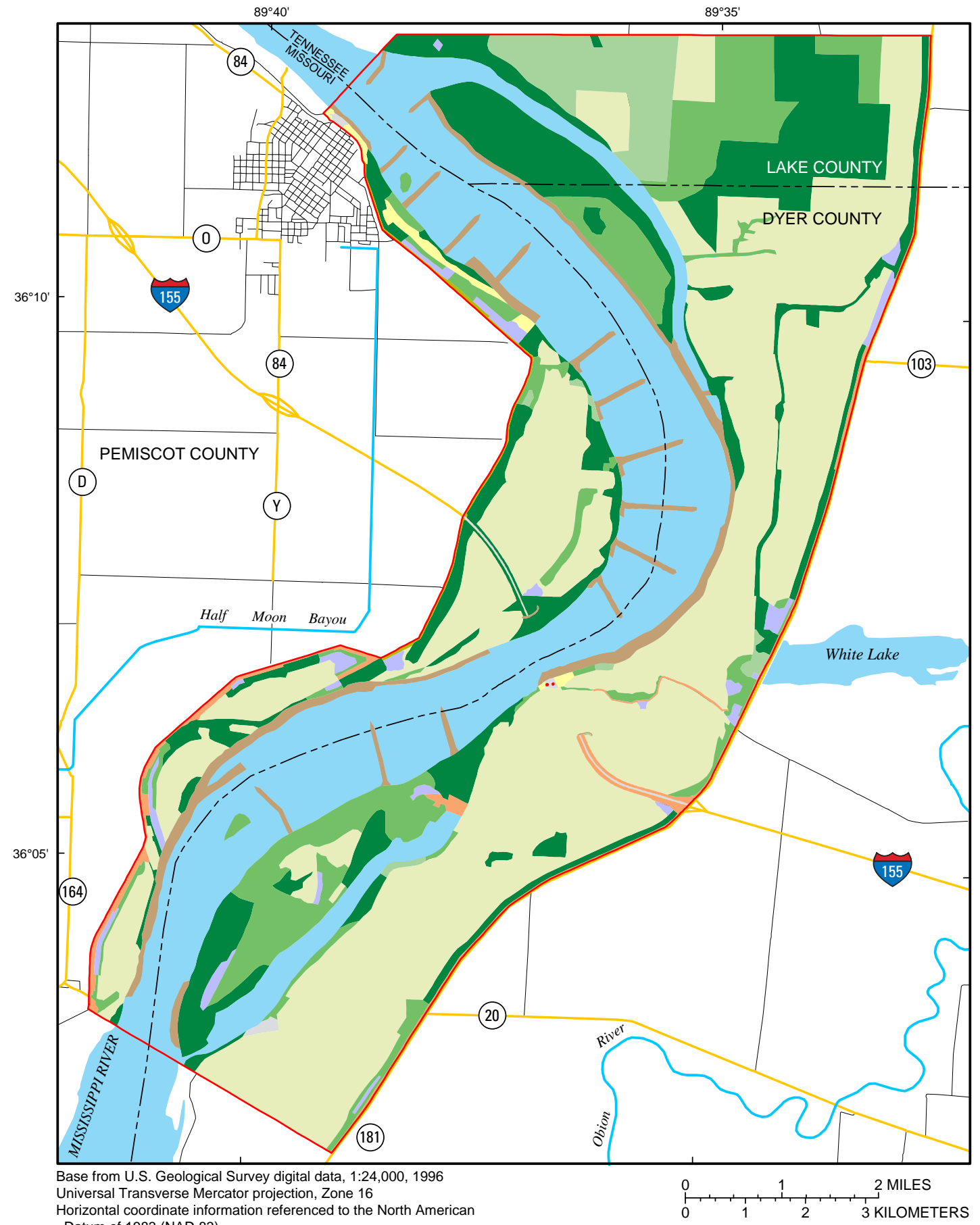

Datum of 1983 (NAD 83)

\section{EXPLANATION}

\section{LAND USE}

Area of no flow

Mississippi River channel

Riprap banks and dikes
Thick timber and thick brush Timber and brush

Thick brush (small trees and scrub)

Row crops (cotton and corn)

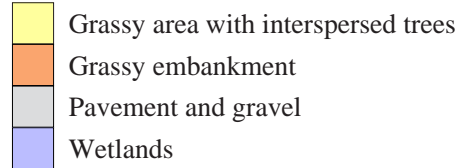

Wetlands

Figure 7. Land-use coverages used in flow simulations on the Mississippi River near Caruthersville, Missouri. 


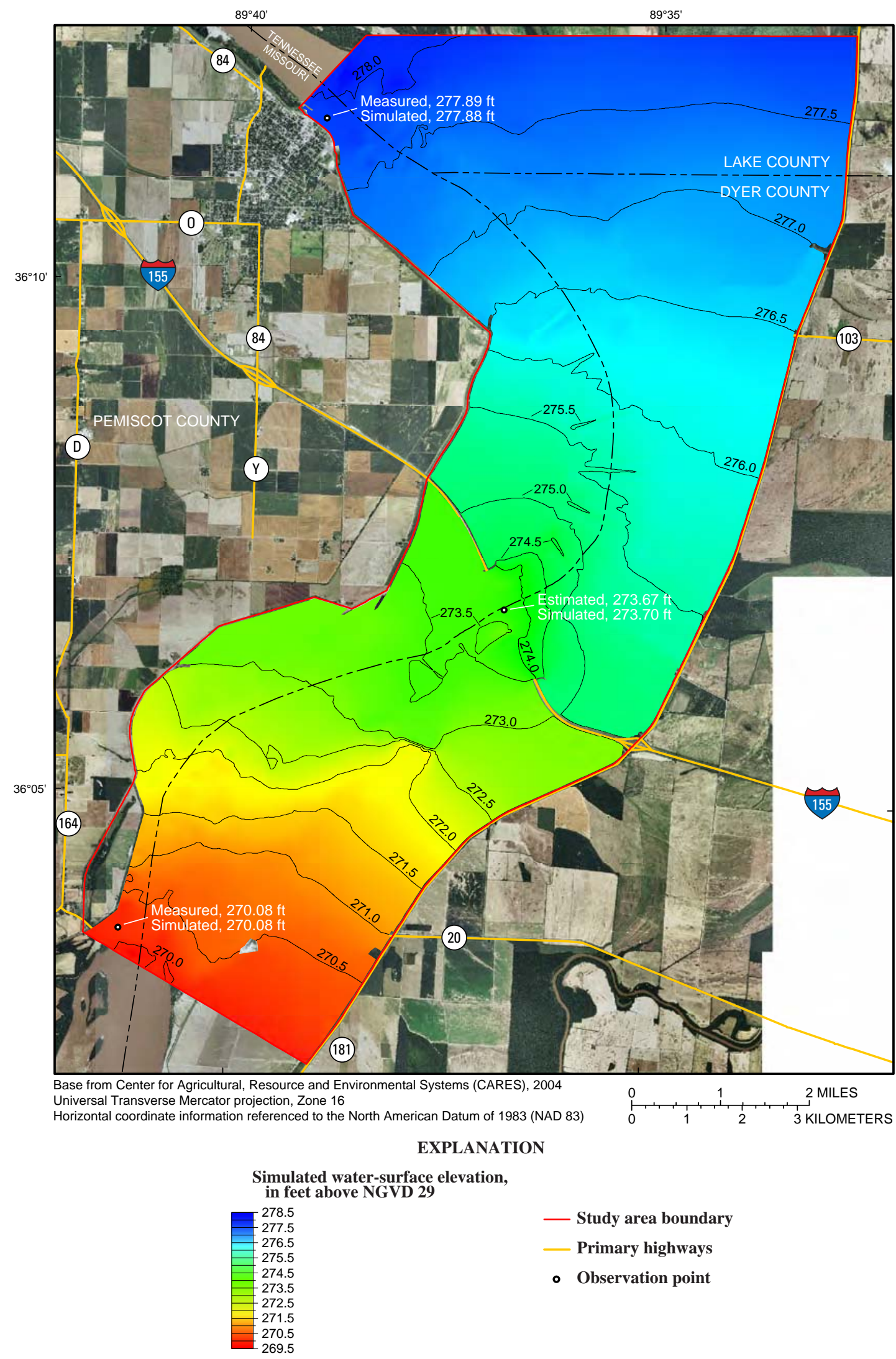

Figure 8. Measured, estimated, and simulated water-surface elevations for the calibration flood of April 4, 1975, on the Mississippi River near Caruthersville, Missouri. 
Table 2. Measured and simulated water-surface elevations for the calibration flood of April 4, 1975, on the Mississippi River near Caruthersville, Missouri.

[ft, feet]

\begin{tabular}{lccc}
\hline \multicolumn{1}{c}{ Location } & \multicolumn{3}{c}{ Water-surface elevation } \\
\cline { 2 - 5 } & $\begin{array}{c}\text { Measured } \\
\text { (ft) }\end{array}$ & $\begin{array}{c}\text { Simulated } \\
\text { (ft) }\end{array}$ & $\begin{array}{c}\text { Simulated minus measured } \\
\text { (ft) }\end{array}$ \\
\hline Gage at Caruthersville, Missouri (near upstream boundary of model) & 277.89 & 277.88 & -0.01 \\
Interstate 155 bridge over the Mississippi River (structure A-1700) & ${ }^{2} 273.67$ & 273.70 & .03 \\
Gage at Cottonwood Point, Missouri (near downstream boundary of model) & 270.08 & 270.08 & 0 \\
\hline
\end{tabular}

${ }^{a}$ Water-surface elevation estimated using the average slope of the water surface between the gages at the peak of the flood.

\section{Simulation of Project Design Flood}

The project design flood (PDF) is a generic term used by the USACE to designate the maximum flood that will be safely contained by the mainline levees in a particular area (Barry Bruchman, oral commun., 2007). The impendent levee overtopping discharge is a situation where maximum scour at a bridge possibly can occur because all the flow is contained within the levees and forced through the bridge opening. If the levees are overtopped, the flow can expand across the vast flood plains beyond the mainline levees, which allows a part of the total flow to bypass the bridge and causes the water-surface elevation and velocities at the bridge to decrease, reducing the potential for scour at the bridge. Another situation for the possibility of maximum scour exists when approach road embankments are about to be overtopped because all of the flow on the adjacent flood plain is forced through the bridge opening instead of being able to flow over the road embankment (Richardson and Davis, 2001). At structure A-1700, the impendent road overtopping discharge would approximately equal the PDF because the road embankment elevations are similar to the mainline levee elevations near structure A-1700; therefore, the PDF was simulated to provide hydraulic parameters for a possible worst-case scenario for scour at structure A-1700.

As with the 100-year flood, the USACE has determined the stage and discharge for the PDF at the Caruthersville gage, but not at the Cottonwood Point gage; therefore, a similar scheme was employed for the simulation of the PDF as was used for the 100-year flood. At the Caruthersville gage, the USACE has determined the stage for the PDF to be $283.80 \mathrm{ft}$ $(+/-0.05 \mathrm{ft})$, with a corresponding discharge of $1,974,000 \mathrm{ft}^{3} / \mathrm{s}$ (Barry Bruchman, oral commun., 2007). The simulation of the PDF used the material and hydraulic properties determined in the calibration simulation and a known upstream boundary discharge of 1,974,000 ft $\mathrm{ft}^{3} / \mathrm{s}$; however, a downstream boundary condition again was assumed and adjusted until the simulated water-surface elevation at the Caruthersville gage matched the known water-surface elevation of $283.80 \mathrm{ft}(+/-0.05 \mathrm{ft})$. The downstream boundary for the PDF simulation initially was spun down to $275.9 \mathrm{ft}$, using the water-surface slope from the calibration simulation $(0.57 \mathrm{ft} / \mathrm{mi})$; however, the simulated water-surface elevation at the Caruthersville gage for this downstream condition was $283.41 \mathrm{ft}$. Raising the downstream water-surface elevation to $276.8 \mathrm{ft}$ resulted in a simulated water-surface elevation at the gage of $283.74 \mathrm{ft}$, and raising the downstream water-surface elevation to $276.9 \mathrm{ft}$ resulted in a simulated water-surface elevation near the gage of 283.82 $\mathrm{ft}$. This latter downstream condition corresponds to a surfacewater slope of $0.50 \mathrm{ft} / \mathrm{mi}$, which is somewhat lower than the calibration simulation slope of $0.57 \mathrm{ft} / \mathrm{mi}$. The change in slope likely is the result of decreasing flow resistance with increasing depth, particularly on the flood plain. The simulated water-surface elevations for the entire study area for the PDF are shown in figure 10.

Simulated results indicate that the mean water-surface elevation at structure A-1700 was $279.98 \mathrm{ft}$ (fig. 10) and the maximum depth was $101.1 \mathrm{ft}$ about $3 \mathrm{mi}$ downstream from structure A-1700 along the right bank. Simulated depths and velocities from the simulation of the PDF in the vicinity of structure A-1700 are shown in figures 11 and 12 . The maximum depth near structure A-1700 was $98.8 \mathrm{ft}$ at the base of the left bank immediately downstream from structure A-1700 (fig. 11). The velocity vectors (velocity magnitudes and direction computed at various points) indicate the direction of flow around the left and right abutments and guidebanks and also show flow at an angle across the flood plain near the bridge (fig. 11). Velocity magnitudes reach a maximum of $11.2 \mathrm{ft} / \mathrm{s}$ immediately downstream from structure A-1700 on the left side of the main channel (fig. 12). Velocity magnitudes around the left guidebank are similar to the main channel upstream from the bridge (fig. 12). Similar results were observed for the calibration flood and 100-year flood simulations.

\section{Evaluation of Bridge Scour}

Scour is the removal of the channel bed and bank material by flowing water and is the leading cause of bridge failures in the United States (Richardson and Davis, 2001). Total scour is divided into three primary components: general scour, which refers to long-term geomorphicological processes that cause degradation (lowering), aggradation (filling), or lateral shifting 


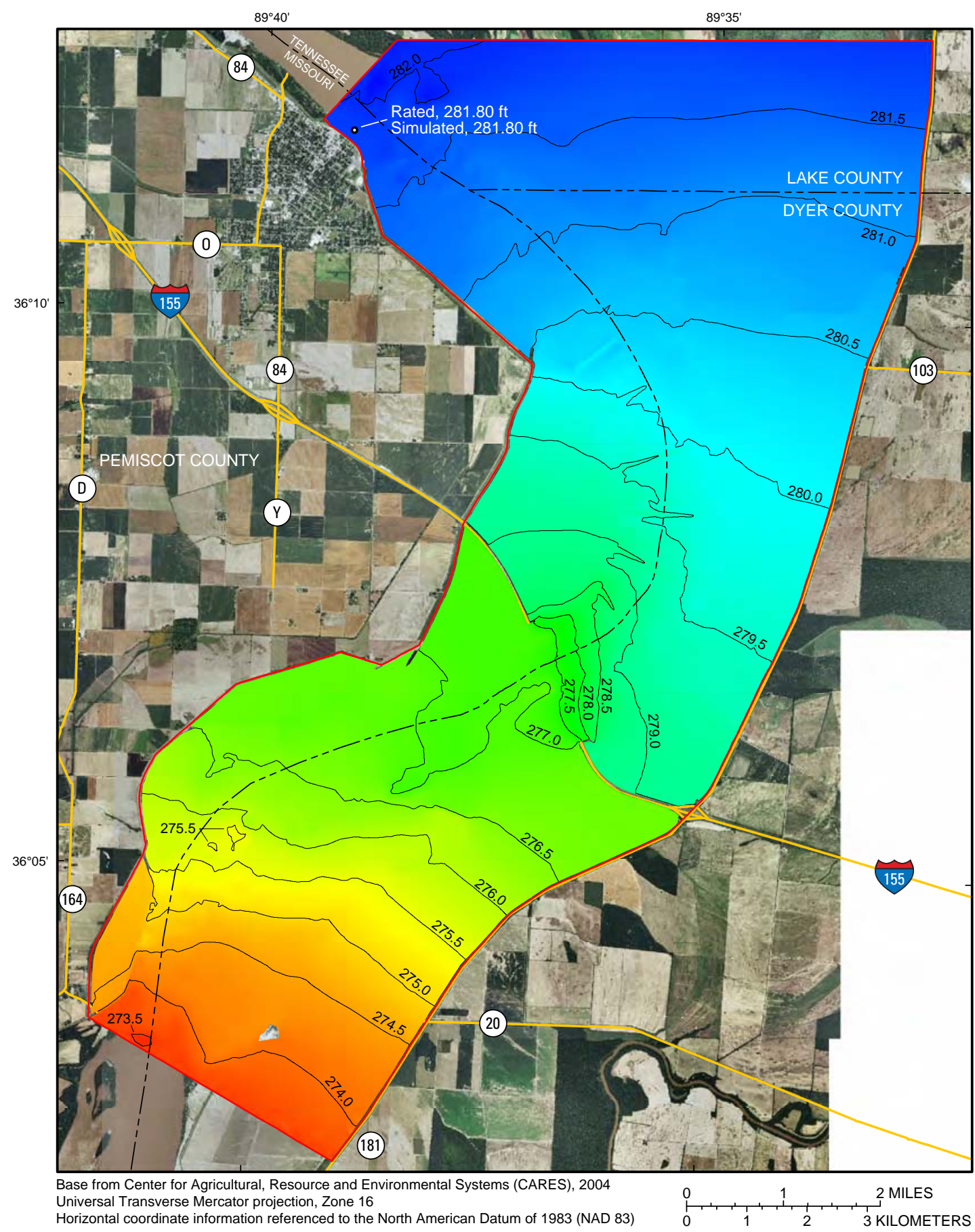

EXPLANATION

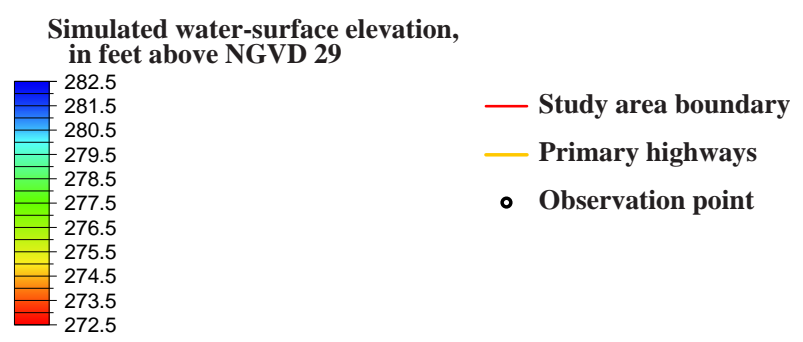

Figure 9. Rated and simulated water-surface elevations for the 100-year flood on the Mississippi River near Caruthersville, Missouri. 


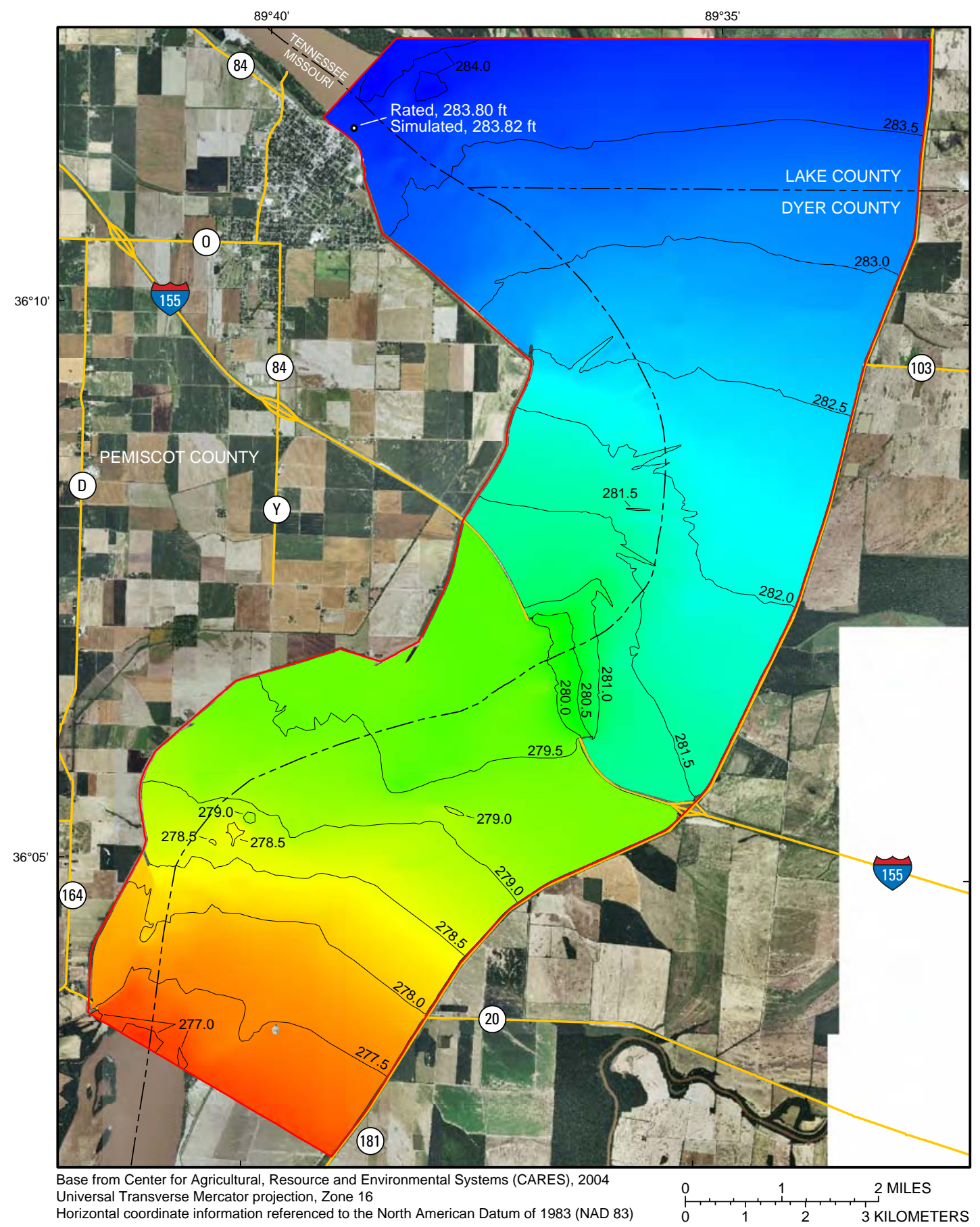

EXPLANATION

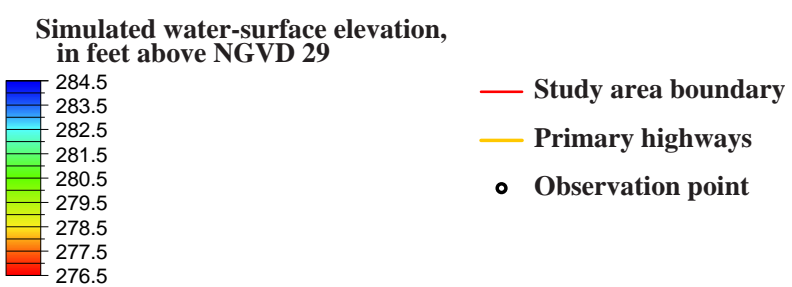

Figure 10. Rated and simulated water-surface elevations for the project design flood on the Mississippi River near Caruthersville, Missouri. 


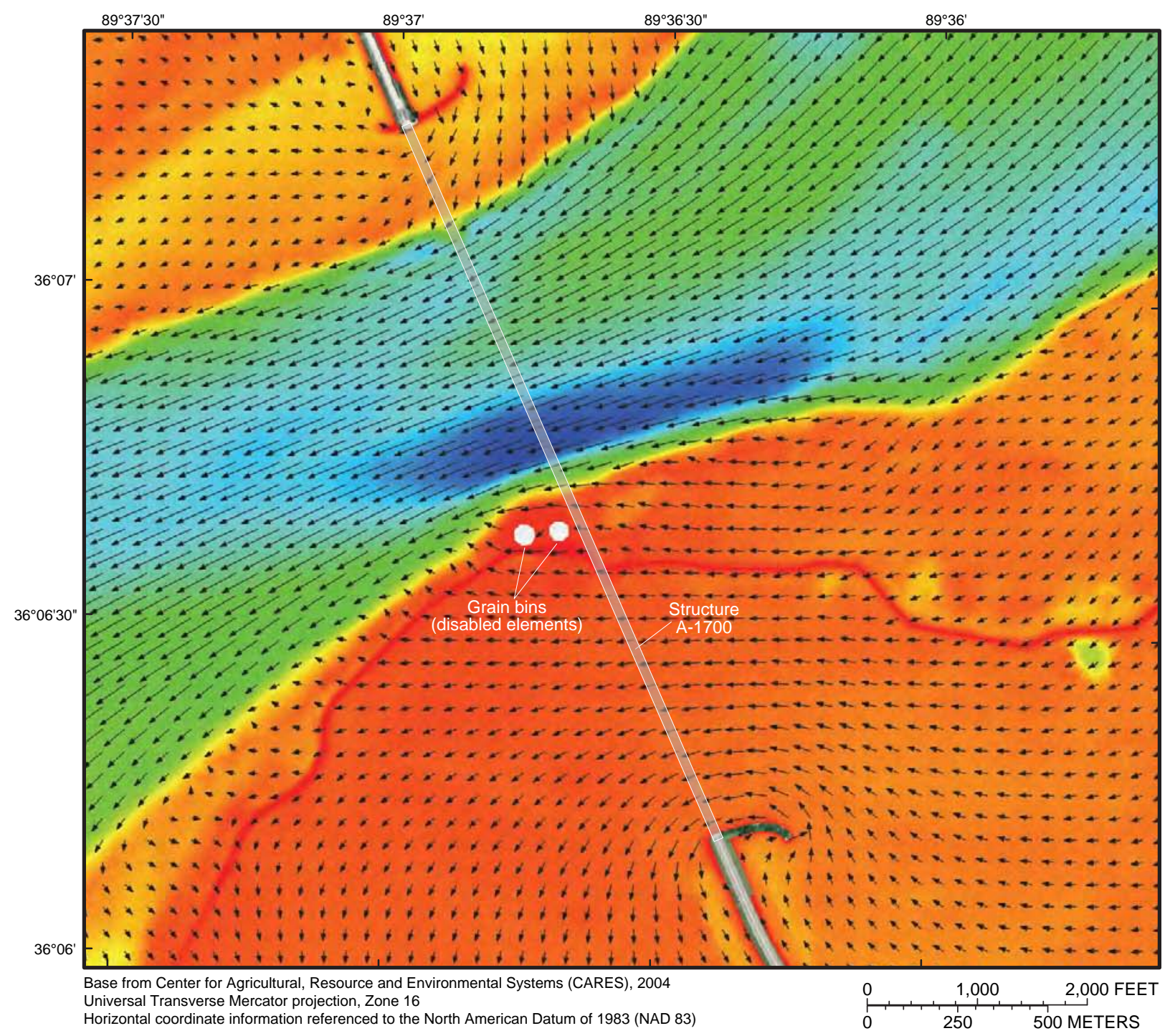

\section{EXPLANATION}

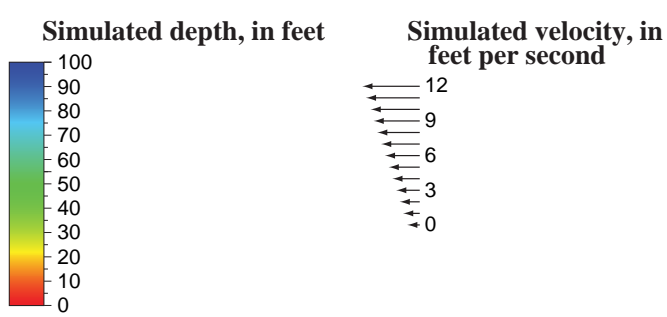

Figure 11. Simulated depths and velocity vectors in the vicinity of structure A-1700 for the project design flood on the Mississippi River near Caruthersville, Missouri. 


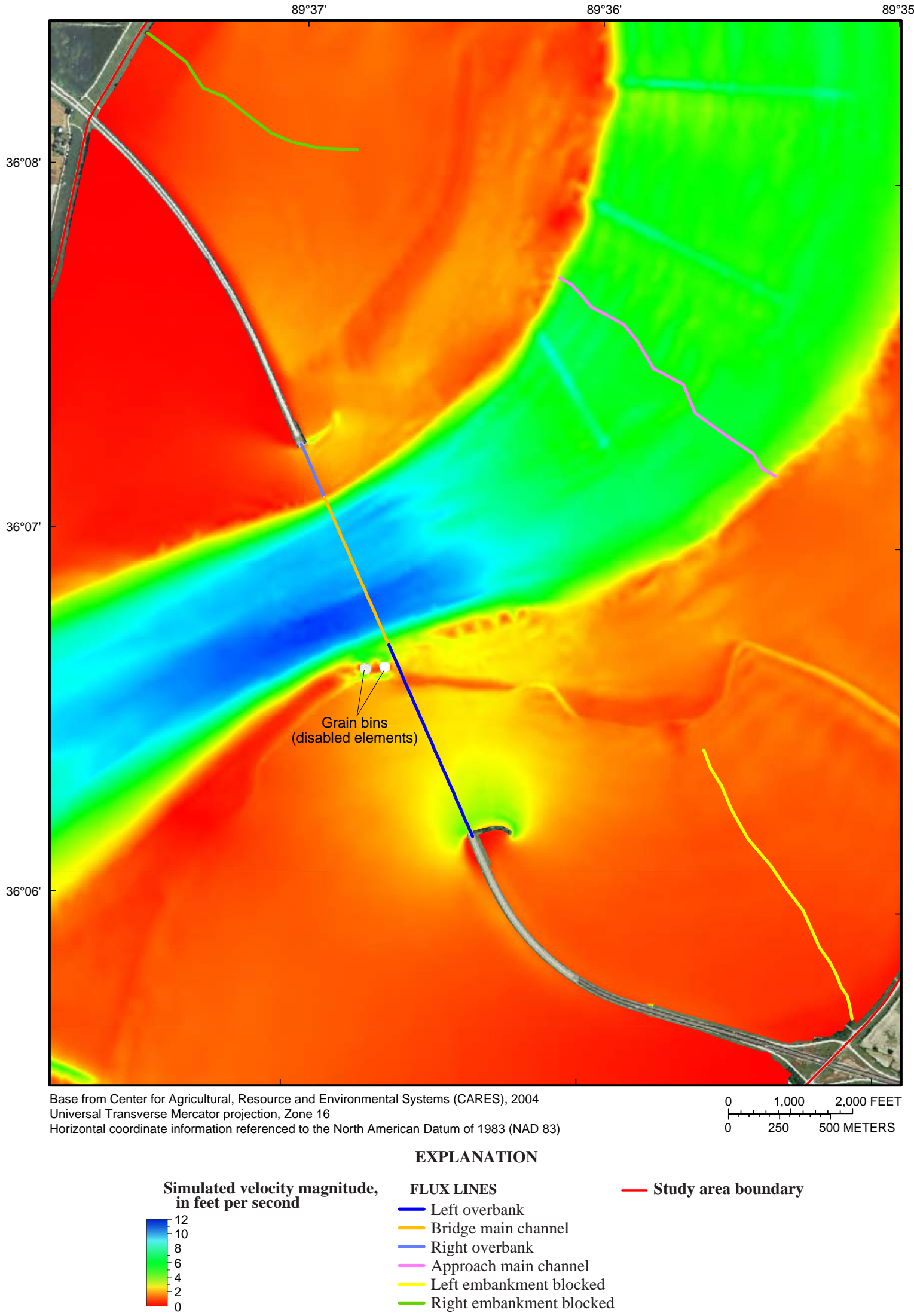

Figure 12. Simulated velocity magnitudes for project design flood and flux lines used for scour parameter determinations on the Mississippi River near Caruthersville, Missouri. 
of the natural channel; contraction scour, which refers to the erosion of material that occurs when the cross-sectional flow area of the stream is decreased or contracted; and local scour, which refers to the localized erosion of material caused by flow vortex action that forms near bridge piers and abutments (Richardson and Davis, 2001). Although scour processes continually are at work, the processes are accelerated during highflow conditions, and the potential for scour-related concerns at a bridge tend to increase during such floods.

Using techniques outlined in Hydraulic Engineering Circular No. 18 (HEC-18), entitled "Evaluating Scour at Bridges" (Richardson and Davis, 2001), the various components of scour can be estimated from hydraulic parameters determined from numerical models and bridge parameters obtained from bridge plans and surveys done of the site. Long-term degradation or aggradation can be determined from a comparison of the present channel cross section at the bridge with the channel cross section at the time of bridge construction. General contraction scour depths can be estimated using the ratio of the discharge in the approach channel to the discharge in the bridge opening and the ratio of the width of the approach channel to the width of the bridge opening. Local pier scour depths can be estimated at each pier or bent using flow velocity, flow depth, pier width, pier length, and flow approach angle. Abutment scour depths can be estimated for the road embankment on each side of the bridge using the discharge and flow area on the flood plain that is blocked by each road embankment.

\section{Scour Depth Computations in the Two- Dimensional Model}

The Flo2DH model is able to compute general contraction scour at each node, using a critical bed shear stress $\left(\tau_{0}\right.$, the stress that must be overcome to move a soil particle by the flow) and various other parameters computed by the model during the simulation. Chow (1959) defines $\tau_{0}$ as "permissible tractive force" or "permissible shear force" and provides several tables for estimating $\tau_{0}$ based on material type, particle size, and cohesion. Furthermore, Froehlich (2002) provides guidance for estimating $\tau_{0}$ based on soil cover. However, the critical bed shear stress was difficult to estimate with confidence. The critical bed shear stress for the material in the Mississippi River channel and on the adjacent flood plain was estimated based on the median particle diameter $\left(\mathrm{D}_{50}\right.$, the particle diameter at which 50 percent of the material is coarser and 50 percent is finer) of the material and the type of vegetative cover present. Based on the assigned critical bed shear stress, the general scour depths in the channel computed by the model were exceptionally large (about 1,000 ft of scour in some locations); therefore, the general contraction scour depths computed by the model were not used, even though the general scour depths computed for the flood plain were more reasonable.
Local pier scour also can be computed by the model when the user defines the location, size, alignment, and various other parameters for each pier or bent. However, the pier scour depths computed by the model are for the existing channel configuration. Historically, the scour assessments performed for MoDOT are for the most severe conditions, which allows for a dynamic channel configuration such as a shift in the channel thalweg during a flood (Huizinga and Rydlund, 2004); therefore, the pier scour depths computed by the model were not used as the pier scour depths for structure A-1700.

\section{Scour Depth Computations Using Two- Dimensional Simulation Results}

To obtain the parameters required for scour depth computations from the simulation results, flux lines were delineated at critical locations of interest in the finite-element mesh. The various node strings used as flux lines are indicated in figure 12. Flux lines were delineated across the flood plain under the left (east) approach spans of structure A-1700 from the left abutment to top of the left bank (left overbank); the main channel of the Mississippi River from the top of the left (east) bank to the top of the right (west) bank under the main spans of structure A-1700 (bridge main channel); the flood plain under the right (west) approach spans of structure A-1700 from the right abutment to top of the right bank (right overbank); the upstream channel of the Mississippi River from the top of the left (east) bank to the top of the right (west) bank about 4,750 ft upstream from structure A-1700 (approach main channel); the left (east) flood plain upstream from the left (east) embankment from the east mainline levee to a point where the velocity vector flow lines (if extended) would intersect the toe of the left abutment (left embankment blocked); and the right (west) flood plain upstream from the right (west) embankment from the west mainline levee to a point where the velocity vector flow lines (if extended) would intersect the toe of the right abutment (right embankment blocked). The velocity magnitude, depth of flow, and water-surface elevation assigned to each node in the flux lines were obtained from the simulations and used to determine the cross-sectional area of flow, average depth, and average flow velocity at each flux line. Additionally, the average elevation of the energy grade line (the sum of the land-surface elevation, the depth of flow, and the velocity head, $V^{2} / 2 g$, where $V$ is the mean velocity of flow in feet per second and $g$ is the acceleration of gravity in feet per second squared) was determined at the bridge main channel and approach main channel flux lines for use in the contraction scour computations.

A cross section of the bridge opening of structure A-1700 is shown in figure 4 , along with bridge substructure and superstructure details and other information pertaining to the scour analysis. The channel shows some long-term aggradation in the thalweg and degradation on the right side, as indicated by the difference in the land surface in 1973 from MoDOT plans (Missouri Department of Transportation, 1974) and the current 
(2004) land surface obtained from the USACE ground-elevation data. The left overbank has an area of degradation near the left abutment, and the right overbank has an area of degradation near the top of the right bank and an area of aggradation in the middle of the overbank.

Core logs from boreholes (hereinafter referred to as "bore logs") drilled by the USACE on the left bank upstream from structure A-1700 (Derrick Smith, written commun., 2007) indicate the material near the land surface is composed of sandy silt and silty clay, and transitions into a fine to medium sand [ $\mathrm{D}_{50}$ ranging from 0.60 to 0.90 millimeters (mm)] about 50 to $60 \mathrm{ft}$ below the land surface. Bore logs from MoDOT plans (Missouri Department of Transportation, 1974) for the flood plain under both approach spans also indicate the material on the flood plain consists of a sandy silt and clay near the surface, changing to fine and medium sand below the surface. A sample collected from the land surface under the left approach spans of structure A-1700 confirmed the material on the left flood plain is a sandy silt with clay $\left(\mathrm{D}_{50}=0.04 \mathrm{~mm}\right)$ as indicated by the USACE and MoDOT bore logs. The material in the channel was assumed to consist of the fine to medium sand present at depth in the USACE bore $\operatorname{logs}\left(\mathrm{D}_{50}=0.90\right.$ $\mathrm{mm}$ ), based on MoDOT bore logs near the main-channel piers and visual inspection of material deposited on the banks and on bars in the channel.

The estimated contraction scour depths for structure A-1700 were computed using Laursen's live-bed contraction scour equation for the main channel (table 3) and Laursen's clear-water contraction scour equation for the left and right overbanks (table 4), assuming an infinite depth of erosive material and a homogeneous particle-size distribution (Richardson and Davis, 2001). Based on the velocities and depths obtained from the Flo2DH analysis and the median diameter of the material in the channel $\left(\mathrm{D}_{50}=0.90 \mathrm{~mm}\right)$, a critical velocity of incipient motion, $V_{\mathrm{c}}$, in the main channel was calculated using Laursen's equation (Richardson and Davis, 2001) for each of the three simulations. Because the critical velocity, $V_{\mathrm{c}}$, was less than the mean velocity in the approach main channel for all three of the discharge simulations used in this analysis, a live-bed scour scenario was assumed to exist in the main channel. Conversely, because of the extensive vegetation on the flood plain upstream from the bridge and the lower velocities on the flood plain near the bridge, a clear-water scour scenario (wherein no bed material is transported) was assumed to exist on the overbank areas under the approach spans of structure A-1700. The median particle diameter of the surface material on the left flood plain $\left(\mathrm{D}_{50}=0.04 \mathrm{~mm}\right)$ also was used to represent the right flood plain.

The predicted contraction scour depths for the calibration flood were 13.8 and 5.0 feet for main channel and left overbank, respectively; a value of 0 feet was predicted for the contraction scour depth on the right overbank for the calibration flood. The predicted main-channel contraction scour depth for the 100-year flood was 17.7 feet, with predicted overbank contraction scour depths of 14.4 and 2.6 feet for the left and right overbanks, respectively. The predicted main-channel

Table 3. Predicted live-bed contraction scour depths and parameters used to compute main-channel contraction scour on the Mississippi River near Caruthersville, Missouri.

$[\mathrm{ft} / \mathrm{s}$, cubic feet per second; $\mathrm{ft} / \mathrm{s}$, feet per second; ft, feet]

\begin{tabular}{|c|c|c|c|}
\hline \multirow[b]{2}{*}{ Parameter required to compute scour depth } & \multicolumn{3}{|c|}{ Flood } \\
\hline & Calibration & 100-year & Project design \\
\hline Flood discharge $\left(\mathrm{ft}^{3} / \mathrm{s}\right)$ & $1,658,000$ & $1,960,000$ & $1,974,000$ \\
\hline Critical velocity of incipient motion $(\mathrm{ft} / \mathrm{s})$ & 3.11 & 3.15 & 3.17 \\
\hline Average velocity in approach main channel (ft/s) & 5.94 & 6.23 & 5.85 \\
\hline Type of scour & Live-bed & Live-bed & Live-bed \\
\hline \multicolumn{4}{|c|}{ Approach section (fig. 12) } \\
\hline Discharge $\left(\mathrm{ft}^{3} / \mathrm{s}\right)$ & $1,533,000$ & $1,732,000$ & $1,696,000$ \\
\hline Channel width (ft) & 4,840 & 4,840 & 4,840 \\
\hline Average depth (ft) & 53.3 & 57.4 & 59.9 \\
\hline Energy grade line elevation (ft) & 275.65 & 279.66 & 282.02 \\
\hline \multicolumn{4}{|c|}{ Bridge section (fig. 12) } \\
\hline Discharge $\left(\mathrm{ft}^{3} / \mathrm{s}\right)$ & $1,610,000$ & $1,849,000$ & $1,820,000$ \\
\hline Channel width minus pier/bent widths (ft) & 2,600 & 2,600 & 2,600 \\
\hline Average depth (ft) & 69.1 & 72.9 & 75.6 \\
\hline Energy grade line elevation (ft) & 274.84 & 278.72 & 281.18 \\
\hline Computed contraction scour depth (ft) & 13.8 & 17.7 & 19.4 \\
\hline
\end{tabular}


Table 4. Predicted clear-water contraction scour depths and parameters used to compute overbank contraction scour on the Mississippi River near Caruthersville, Missouri.

$\left[\mathrm{ft}^{3} / \mathrm{s}\right.$, cubic feet per second; $\mathrm{ft}$, feet]

\begin{tabular}{lccc}
\hline & \multicolumn{3}{c}{ Flood } \\
\cline { 2 - 4 } \multicolumn{1}{c}{ Parameter required to compute scour depth } & Calibration & $\mathbf{1 0 0}$-year & Project design \\
\hline Flood discharge $\left(\mathrm{ft}^{3} / \mathrm{s}\right)$ & $1,658,000$ & $1,960,000$ & $1,974,000$ \\
\hline & Left overbank section (fig. 12) \\
\hline Discharge $\left(\mathrm{ft}^{3} / \mathrm{s}\right.$ ) & 40,000 & 91,800 & 129,600 \\
Section width minus pier/bent widths (ft) & 3,320 & 3,320 & 3,320 \\
Average depth (ft) & 7.7 & 11.4 & 14.0 \\
Computed contraction scour depth (ft) & $\mathbf{5 . 0}$ & $\mathbf{1 4 . 4}$ & $\mathbf{2 0 . 6}$ \\
\hline & Right overbank section (fig. 12) \\
\hline Discharge (ft 3 /s) & 9,140 & 19,400 & 25,200 \\
Section width minus pier/bent widths (ft) & 916 & 916 & 916 \\
Average depth (ft) & 14.3 & 17.9 & 20.5 \\
Computed contraction scour depth (ft) & $\mathbf{0}$ & $\mathbf{2 . 6}$ & $\mathbf{5 . 2}$ \\
\hline
\end{tabular}

contraction scour depth for the project design flood was 19.4 feet, with predicted overbank contraction scour depths of 20.6 and 5.2 feet for the left and right overbanks, respectively.

The local pier scour depths were computed using the Colorado State University (CSU) pier scour equation (Richardson and Davis, 2001). The piers of the main span consist of round-nosed columns on caisson foundations and were analyzed as round-nosed columns using their overall length and width according to HEC-18 guidelines (Richardson and Davis, 2001). The bents of the main span consist of two cylindrical columns $6.5 \mathrm{ft}$ in diameter spaced $46 \mathrm{ft}$ on center supported on pile foundations; these bents were analyzed as a single column because the spacing between the columns was greater than 5 times the column diameter, and HEC-18 guidelines state that for multiple columns spaced 5 column-diameters or greater apart the predicted scour depth should be limited to 1.2 times the local scour of a single column if debris is not a concern at the site (Richardson and Davis, 2001). The bents of the left and right approach spans consisted of three cylindrical columns ranging from 3.5 to $6.0 \mathrm{ft}$ in diameter and spaced 29 $\mathrm{ft}$ on center; the bents with a column diameter of $4.5 \mathrm{ft}$ or less were analyzed as a single column because the spacing between the columns was greater than 5 times the column diameter, and the bents with a column diameter of greater than $4.5 \mathrm{ft}$ were analyzed as an equivalent round-nosed pier with a length equal to the 3 times the column diameter. The piers and bents in the main channel were analyzed using the maximum velocity and the maximum depth of flow in the channel under the bridge to account for possible changes in the thalweg during a flood, whereas the piers and bents on the left and right banks and overbanks were analyzed using the depth and velocity at the pier or bent (tables 5-7). The flow angle of attack as determined by Flo2DH for each pier or bent was included in the local pier scour depth computation (tables 5-7).
The predicted contraction scour depths on the left overbank and in the main channel resulted in footing exposure at the bents on the left overbank and on the right bank, as well as at several of the main-channel piers. Therefore, the local pier scour depths computed using the CSU pier scour equation were superseded by local pier scour depths computed using the equations for complex pier foundations (Richardson and Davis, 2001) at these piers and bents (tables 5-7).

The predicted contraction and local pier scour depths computed for the PDF are shown in figures 13 and 14, and the predicted total scour depths (the sum of contraction scour and local pier scour) for the three flood simulations are shown in figures 15 and 16. Predicted scour depths are shown in relation to the current (2004) land surface taken from the groundelevation data provided by the USACE, assuming no scour protection. Predicted total scour depths (contraction and local pier scour) for the calibration flood were the least, whereas the predicted total scour depths for the project design flood generally were the greatest.

The maximum predicted total scour depth for the calibration flood was $66.1 \mathrm{ft}$, occurring at pier 18. The maximum predicted total scour depth for the 100-year flood was $74.6 \mathrm{ft}$, also occurring at pier 18 . The maximum predicted total scour depth for the project design flood was $93.0 \mathrm{ft}$, occurring at pier 20. Based on the predicted total scour depths (figs. 15 and 16), piers 15 through 21 in the main channel and bent 14 on the right bank may be substantially exposed or undermined by a flood equal to or greater than the calibration flood of April 4, 1975, in the absence of scour protection. On the left overbank, nearly all of the bents show footing undermining with moderate pile exposure for the calibration flood of April 4, 1975, and all of the bents show footing undermining with moderate to substantial pile exposure for the 100-year flood and PDF. The 
Table 5. Predicted local pier scour depths and parameters used to compute pier scour for the calibration flood of April 4, 1975, on the Mississippi River near Caruthersville, Missouri.

[ft, feet; ft/s, feet per second; deg, degrees]

\begin{tabular}{|c|c|c|c|c|c|c|c|c|c|}
\hline \multirow[b]{2}{*}{$\begin{array}{c}\text { Pier/ } \\
\text { bent } \\
\text { number }\end{array}$} & \multirow{2}{*}{$\begin{array}{l}\text { Stationing along } \\
\text { centerline from } \\
\text { left (southeast) } \\
\text { end of bridge }{ }^{\mathrm{b}} \\
\text { (ft) }\end{array}$} & \multirow[b]{2}{*}{ Location } & \multirow{2}{*}{$\begin{array}{l}\text { Pier/bent } \\
\text { width at } \\
\text { ground } \\
\text { elevation } \\
\text { (ft) }\end{array}$} & \multirow{2}{*}{$\begin{array}{l}\text { Pier/bent } \\
\text { length at } \\
\text { ground } \\
\text { elevation } \\
\text { (ft) }\end{array}$} & \multirow[b]{2}{*}{ Pier/bent shape } & \multicolumn{3}{|c|}{$\begin{array}{c}\text { Flow parameters at upstream bridge } \\
\text { face from Flo2DH }\end{array}$} & \multirow{2}{*}{$\begin{array}{l}\text { Computed } \\
\text { pier scour } \\
\text { depth } \\
\text { (ft) }\end{array}$} \\
\hline & & & & & & $\begin{array}{l}\text { Depth } \\
\text { (ft) }\end{array}$ & $\begin{array}{l}\text { Velocity } \\
\text { (ft/s) }\end{array}$ & $\begin{array}{l}\text { Angle of } \\
\text { attack } \\
\text { (deg) }\end{array}$ & \\
\hline Bent 59 & 71.0 & Left overbank & 3.5 & c3.5 & Single column $^{\mathrm{c}}$ & 5.90 & 2.23 & 1.8 & d 8.9 \\
\hline Bent 58 & 141.0 & Left overbank & 3.5 & 3.5 & Single column ${ }^{\mathrm{c}}$ & 8.99 & 2.85 & 5.6 & $\mathrm{~d} 6.2$ \\
\hline Bent 57 & 211.0 & Left overbank & 3.5 & 3.5 & Single column ${ }^{\mathrm{c}}$ & 9.37 & 2.71 & 8.0 & $\mathrm{~d} 6.2$ \\
\hline Bent 56 & 281.0 & Left overbank & 3.5 & c3.5 & Single column ${ }^{\mathrm{c}}$ & 9.50 & 2.55 & 9.7 & $\mathrm{~d} 11.8$ \\
\hline Bent 55 & 351.0 & Left overbank & 3.5 & c3.5 & Single column ${ }^{\mathrm{c}}$ & 9.06 & 2.40 & 10.7 & d5 5.9 \\
\hline Bent 54 & 421.0 & Left overbank & 3.5 & 3.5 & Single column ${ }^{c}$ & 9.14 & 2.27 & 10.3 & d5.7 \\
\hline Bent 53 & 491.0 & Left overbank & 3.5 & 3.5 & Single column ${ }^{\mathrm{c}}$ & 9.20 & 2.12 & 8.6 & $\mathrm{~d} 5.3$ \\
\hline Bent 52 & 561.0 & Left overbank & 3.5 & c3.5 & Single column ${ }^{\mathrm{c}}$ & 8.71 & 2.02 & 6.4 & d 9.3 \\
\hline Bent 51 & 631.0 & Left overbank & 4.0 & $c^{c} .0$ & Single column ${ }^{\mathrm{c}}$ & 8.55 & 1.93 & 3.4 & $\mathrm{~d} 8.5$ \\
\hline Bent 50 & 701.0 & Left overbank & 3.5 & c3.5 & Single column ${ }^{c}$ & 8.76 & 1.86 & 3.7 & d 8.5 \\
\hline Bent 49 & 771.0 & Left overbank & 3.5 & c3.5 & Single column ${ }^{\mathrm{c}}$ & 9.23 & 1.82 & 2.9 & $\mathrm{~d} 8.5$ \\
\hline Bent 48 & 841.0 & Left overbank & 4.0 & $c^{4} .0$ & Single column ${ }^{c}$ & 8.47 & 1.78 & 1.4 & $\mathrm{~d} 8.5$ \\
\hline Bent 47 & 911.0 & Left overbank & 4.0 & ${ }^{c} 4.0$ & Single column ${ }^{\mathrm{c}}$ & 8.62 & 1.70 & 2.0 & d 8.8 \\
\hline Bent 46 & 981.0 & Left overbank & 4.0 & $c^{\prime} .0$ & Single column ${ }^{\mathrm{c}}$ & 9.08 & 1.64 & 1.6 & d 8.7 \\
\hline Bent 45 & $1,051.0$ & Left overbank & 4.0 & 4.0 & Single column ${ }^{c}$ & 9.20 & 1.60 & 2.4 & $\mathrm{~d} 8.8$ \\
\hline Bent 44 & $1,121.0$ & Left overbank & 4.0 & 4.0 & Single column ${ }^{\mathrm{c}}$ & 8.88 & 1.57 & 4.9 & d 8.4 \\
\hline Bent 43 & $1,191.0$ & Left overbank & 4.0 & ${ }^{c} 4.0$ & Single column ${ }^{c}$ & 8.75 & 1.47 & 4.6 & $\mathrm{~d} 8.2$ \\
\hline Bent 42 & $1,261.0$ & Left overbank & 4.0 & $c^{4} .0$ & Single column ${ }^{\mathrm{c}}$ & 8.91 & 1.44 & 5.4 & d 8.3 \\
\hline Bent 41 & $1,331.0$ & Left overbank & 4.0 & $c^{\prime} .0$ & Single column ${ }^{\mathrm{c}}$ & 8.56 & 1.43 & 5.0 & $\mathrm{~d} 8.2$ \\
\hline Bent 40 & $1,401.0$ & Left overbank & 4.0 & $c^{\prime} .0$ & Single column ${ }^{\mathrm{c}}$ & 8.20 & 1.40 & 4.3 & $\mathrm{~d} 7.9$ \\
\hline Bent 39 & $1,471.0$ & Left overbank & 4.0 & 4.0 & Single column ${ }^{\mathrm{c}}$ & 7.83 & 1.40 & 5.1 & $\mathrm{~d} 8.1$ \\
\hline Bent 38 & $1,541.0$ & Left overbank & 4.0 & ${ }^{c} 4.0$ & Single column ${ }^{\mathrm{c}}$ & 7.44 & 1.38 & 7.8 & d 8.5 \\
\hline Bent 37 & $1,611.0$ & Left overbank & 4.0 & ${ }^{c} 4.0$ & Single column ${ }^{c}$ & 7.09 & 1.38 & 11.8 & $\mathrm{~d} 9.0$ \\
\hline Bent 36 & $1,681.0$ & Left overbank & 4.0 & 4.0 & Single column ${ }^{\mathrm{c}}$ & 7.08 & 1.37 & 12.8 & $\mathrm{~d} 9.1$ \\
\hline Bent 35 & $1,751.0$ & Left overbank & 4.0 & $c^{4} .0$ & Single column ${ }^{c}$ & 7.49 & 1.38 & 12.9 & $\mathrm{~d} 9.0$ \\
\hline Bent 34 & $1,821.0$ & Left overbank & 4.0 & $c^{c} .0$ & Single column ${ }^{\mathrm{c}}$ & 7.50 & 1.37 & 12.9 & $\mathrm{~d} 9.2$ \\
\hline Bent 33 & $1,891.0$ & Left overbank & 4.0 & 4.0 & Single column ${ }^{\mathrm{c}}$ & 7.47 & 1.35 & 14.7 & d9.3 \\
\hline Bent 32 & $1,961.0$ & Left overbank & 4.0 & ${ }^{c} 4.0$ & Single column ${ }^{\mathrm{c}}$ & 7.39 & 1.34 & 15.7 & $\mathrm{~d} 9.4$ \\
\hline Bent 31 & $2,031.0$ & Left overbank & 4.5 & $` 4.5$ & Single column ${ }^{\mathrm{c}}$ & 7.17 & 1.29 & 16.6 & $\mathrm{~d} 9.8$ \\
\hline Bent 30 & $2,121.0$ & Left overbank & 5.5 & 16.5 & Multiple columns & 6.87 & 1.25 & 16.7 & $\mathrm{~d} 11.7$ \\
\hline Bent 29 & $2,211.0$ & Left overbank & 5.5 & 16.5 & Multiple columns & 6.94 & 1.24 & 17.6 & ${ }^{\mathrm{d}} 11.8$ \\
\hline Bent 28 & $2,301.0$ & Left overbank & 5.5 & 16.5 & Multiple columns & 7.25 & 1.23 & 15.9 & $\mathrm{~d} 11.7$ \\
\hline Bent 27 & $2,391.0$ & Left overbank & 5.5 & 16.5 & Multiple columns & 7.66 & 1.27 & 17.3 & ${ }^{\mathrm{d}} 12.0$ \\
\hline Bent 26 & $2,481.0$ & Left overbank & 5.0 & 15.0 & Multiple columns & 6.19 & 1.39 & 17.8 & $\mathrm{~d} 12.2$ \\
\hline Bent 25 & $2,613.4$ & Left overbank & 6.5 & ${ }^{\mathrm{c}} 6.5$ & Single column ${ }^{c}$ & 3.71 & 0.94 & 62.7 & ${ }^{\mathrm{c}} 6.0$ \\
\hline Bent 24 & $2,848.3$ & Left overbank & 6.5 & c6.5 & Single column ${ }^{\mathrm{c}}$ & 4.23 & 0.78 & 88.1 & 4.7 \\
\hline Bent 23 & $3,083.2$ & Left overbank & 6.5 & ${ }^{c} 6.5$ & Single column ${ }^{\mathrm{c}}$ & 6.77 & 1.58 & 55.3 & c8.3 \\
\hline Bent 22 & $3,318.2$ & Top of left bank & 6.5 & ${ }^{c} 6.5$ & Single column ${ }^{\mathrm{c}}$ & 6.38 & 2.29 & 42.5 & c9.7 \\
\hline
\end{tabular}


Table 5. Predicted local pier scour depths and parameters used to compute pier scour for the calibration flood of April 4, 1975, on the Mississippi River near Caruthersville, Missouri.-Continued

[ft, feet; ft/s, feet per second; deg, degrees]

\begin{tabular}{|c|c|c|c|c|c|c|c|c|c|}
\hline \multirow[b]{2}{*}{$\begin{array}{c}\text { Pier/ } \\
\text { bent } \\
\text { number }^{\mathrm{a}}\end{array}$} & \multirow{2}{*}{$\begin{array}{l}\text { Stationing along } \\
\text { centerline from } \\
\text { left (southeast) } \\
\text { end of bridge } \\
\text { (ft) }\end{array}$} & \multirow[b]{2}{*}{ Location } & \multirow{2}{*}{$\begin{array}{l}\text { Pier/bent } \\
\text { width at } \\
\text { ground } \\
\text { elevation } \\
\quad \text { (ft) }\end{array}$} & \multirow{2}{*}{$\begin{array}{l}\text { Pier/bent } \\
\text { length at } \\
\text { ground } \\
\text { elevation } \\
\text { (ft) }\end{array}$} & \multirow[b]{2}{*}{ Pier/bent shape } & \multicolumn{3}{|c|}{$\begin{array}{c}\text { Flow parameters at upstream bridge } \\
\text { face from Flo2DH }\end{array}$} & \multirow{2}{*}{$\begin{array}{l}\text { Computed } \\
\text { pier scour } \\
\text { depth } \\
\text { (ft) }\end{array}$} \\
\hline & & & & & & $\begin{array}{l}\text { Depth } \\
\text { (ft) }\end{array}$ & $\begin{array}{l}\text { Velocity } \\
\text { (ft/s) }\end{array}$ & $\begin{array}{c}\text { Angle of } \\
\text { attack } \\
\text { (deg) }\end{array}$ & \\
\hline Pier 21 & $3,556.1$ & Left bank & 17.0 & 100.5 & Round-nosed & 35.65 & 5.34 & 7.8 & 32.2 \\
\hline Pier 20 & $4,476.0$ & Main channel & 21.0 & 104.5 & Round-nosed & e92.73 & ${ }^{\mathrm{e}} 10.53$ & 2.2 & 42.5 \\
\hline Pier 18 & $5,233.8$ & Main channel & 7.5 & 53.5 & Round-nosed & e92.73 & ${ }^{\mathrm{e}} 10.53$ & 0.7 & $\mathrm{~d} 52.3$ \\
\hline Pier 17 & $5,468.8$ & Main channel & 7.5 & 53.5 & Round-nosed & e92.73 & ${ }^{\mathrm{e}} 10.53$ & 3.1 & $\mathrm{~d} 33.0$ \\
\hline Pier 16 & $5,703.7$ & Main channel & 7.5 & 53.5 & Round-nosed & e92.73 & ${ }^{\mathrm{e}} 10.53$ & 3.8 & $\mathrm{~d} 34.2$ \\
\hline Pier 15 & $5,938.6$ & Right bank & 7.5 & 53.5 & Round-nosed & 52.25 & 7.21 & 3.3 & $\mathrm{~d} 41.2$ \\
\hline Bent 11 & $6,341.0$ & Right overbank & 6.0 & 18.0 & Multiple columns & 12.56 & 0.79 & 63.8 & 8.9 \\
\hline Bent 10 & $6,431.0$ & Right overbank & 6.0 & 18.0 & Multiple columns & 13.70 & 0.79 & 50.2 & 8.7 \\
\hline Bent 9 & $6,521.0$ & Right overbank & 6.0 & 18.0 & Multiple columns & 12.83 & 0.76 & 39.1 & 7.9 \\
\hline Bent 8 & $6,611.0$ & Right overbank & 5.5 & 16.5 & Multiple columns & 12.86 & 0.80 & 30.5 & 7.1 \\
\hline Bent 7 & $6,681.0$ & Right overbank & 5.0 & 15.0 & Multiple columns & 13.62 & 0.86 & 23.5 & 6.4 \\
\hline Bent 6 & $6,751.0$ & Right overbank & 5.0 & 15.0 & Multiple columns & 14.22 & 0.90 & 16.5 & 6.0 \\
\hline Bent 5 & $6,821.0$ & Right overbank & 5.0 & 15.0 & Multiple columns & 14.74 & 0.93 & 9.4 & 5.3 \\
\hline Bent 4 & $6,891.0$ & Right overbank & 5.0 & 15.0 & Multiple columns & 15.09 & 0.99 & 5.1 & 4.9 \\
\hline Bent 3 & $6,961.0$ & Right overbank & 4.5 & c 4.5 & Single column ${ }^{c}$ & 15.56 & 1.14 & 1.6 & ${ }^{c} 5.2$ \\
\hline
\end{tabular}

aPier/bent number corresponds to bridge plans from Missouri Department of Transportation (1974).

${ }^{\mathrm{b}}$ Stationing is the distance from the left abutment fill face (as viewed facing downstream).

"'Pier/bent length at ground elevation" and "Pier/bent shape" are for a single column of a multiple column bent because the spacing between the columns is greater than 5 times the column diameter. The computed pier scour depth at this bent is 1.2 times the local scour of a single column, based on guidelines in Hydraulic Engineering Circular No. 18 (Richardson and Davis, 2001), except for those with complex pier foundation exposure after contraction scour (footnote d).

${ }^{\mathrm{d} C}$ Computed contraction scour depths resulted in footing or pile exposure at this pier or bent. Local pier scour depths were computed using equations for complex pier foundations (Richardson and Davis, 2001).

${ }^{\mathrm{e}}$ The maximum depth and velocity in the main channel were used to compute pier scour depth to account for the possibility of a shift in the channel thalweg. 
Table 6. Predicted local pier scour depths and parameters used to compute pier scour for the 100-year flood on the Mississippi River near Caruthersville, Missouri.

[ft, feet; ft/s, feet per second; deg, degrees]

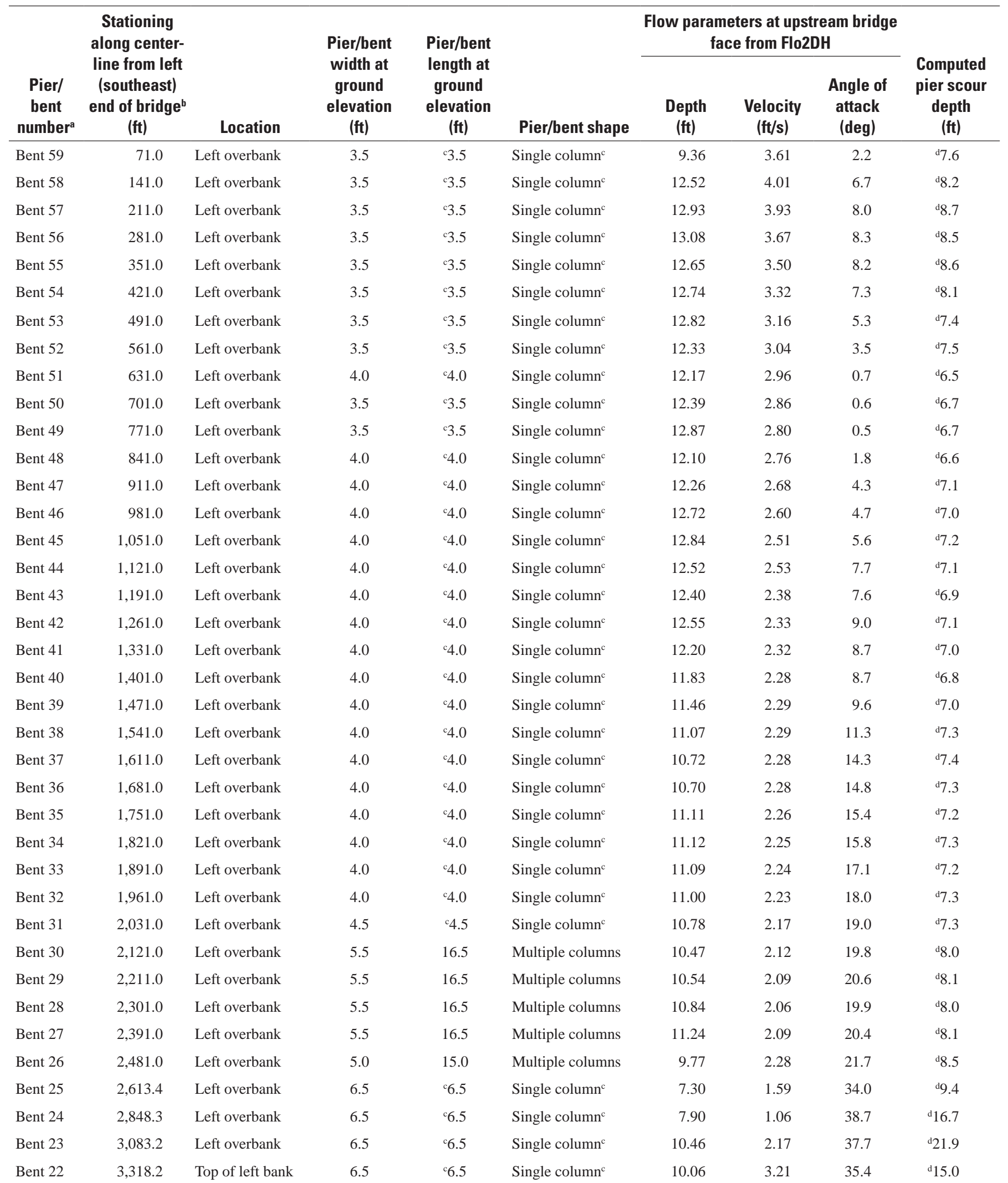


Table 6. Predicted local pier scour depths and parameters used to compute pier scour for the 100-year flood on the Mississippi River near Caruthersville, Missouri.-Continued

[ft, feet; ft/s, feet per second; deg, degrees]

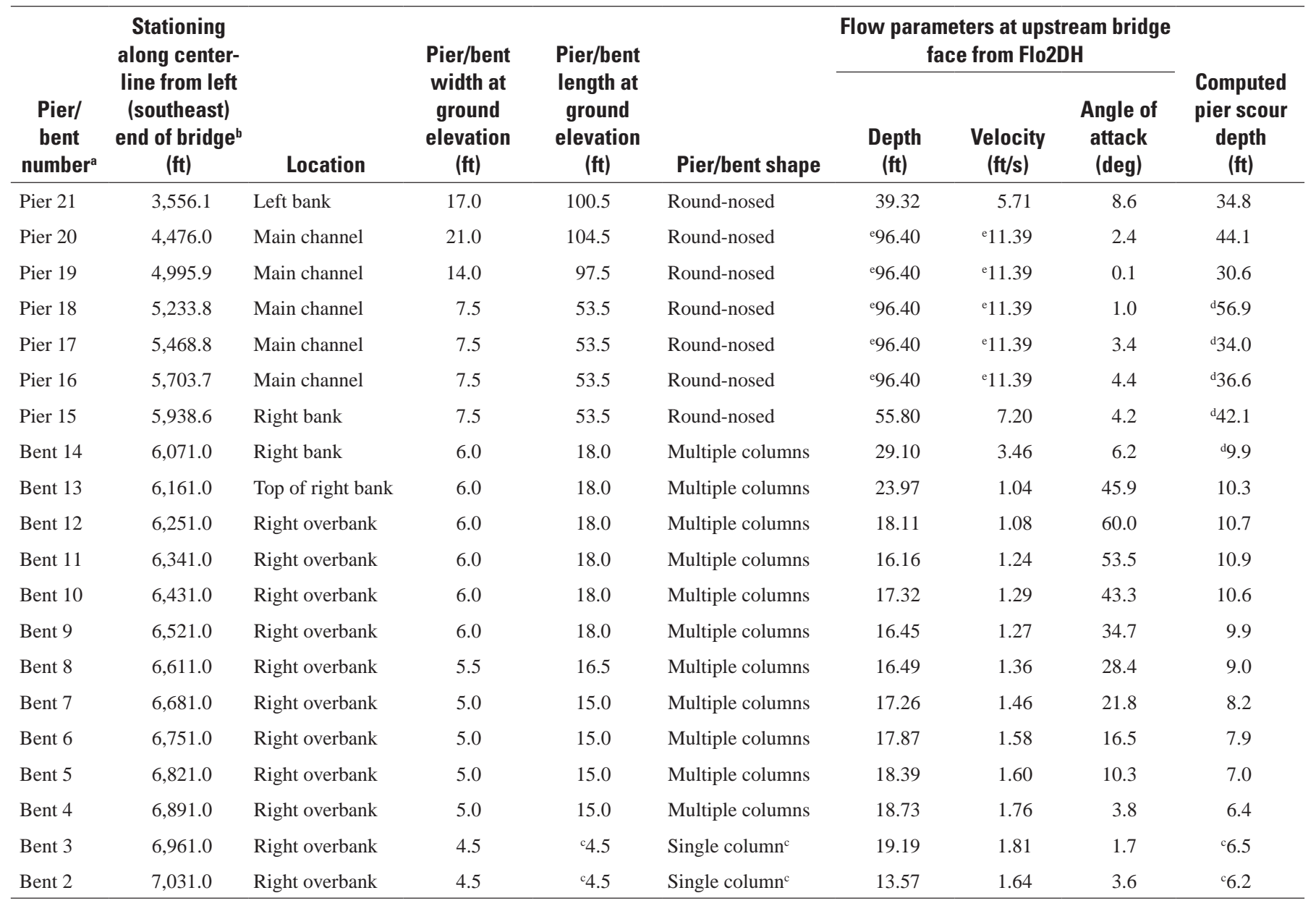

aPier/bent number corresponds to bridge plans from Missouri Department of Transportation (1974).

bStationing is the distance from the left abutment fill face (as viewed facing downstream).

"'Pier/bent length at ground elevation" and "Pier/bent shape" are for a single column of a multiple column bent because the spacing between the columns is greater than 5 times the column diameter. The computed pier scour depth at this bent is 1.2 times the local scour of a single column, based on guidelines in Hydraulic Engineering Circular No. 18 (Richardson and Davis, 2001), except for those with complex pier foundation exposure after contraction scour (footnote d).

${ }^{\mathrm{d} C o m p u t e d ~ c o n t r a c t i o n ~ s c o u r ~ d e p t h s ~ r e s u l t e d ~ i n ~ f o o t i n g ~ o r ~ p i l e ~ e x p o s u r e ~ a t ~ t h i s ~ p i e r ~ o r ~ b e n t . ~ L o c a l ~ p i e r ~ s c o u r ~ d e p t h s ~ w e r e ~ c o m p u t e d ~ u s i n g ~ e q u a t i o n s ~ f o r ~}$ complex pier foundations (Richardson and Davis, 2001).

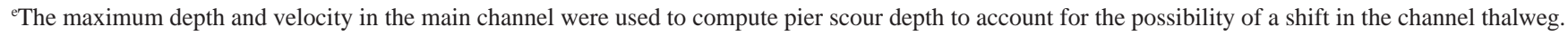


Table 7. Predicted local pier scour depths and parameters used to compute pier scour for the project design flood on the Mississippi River near Caruthersville, Missouri.

[ft, feet; ft/s, feet per second; deg, degrees]

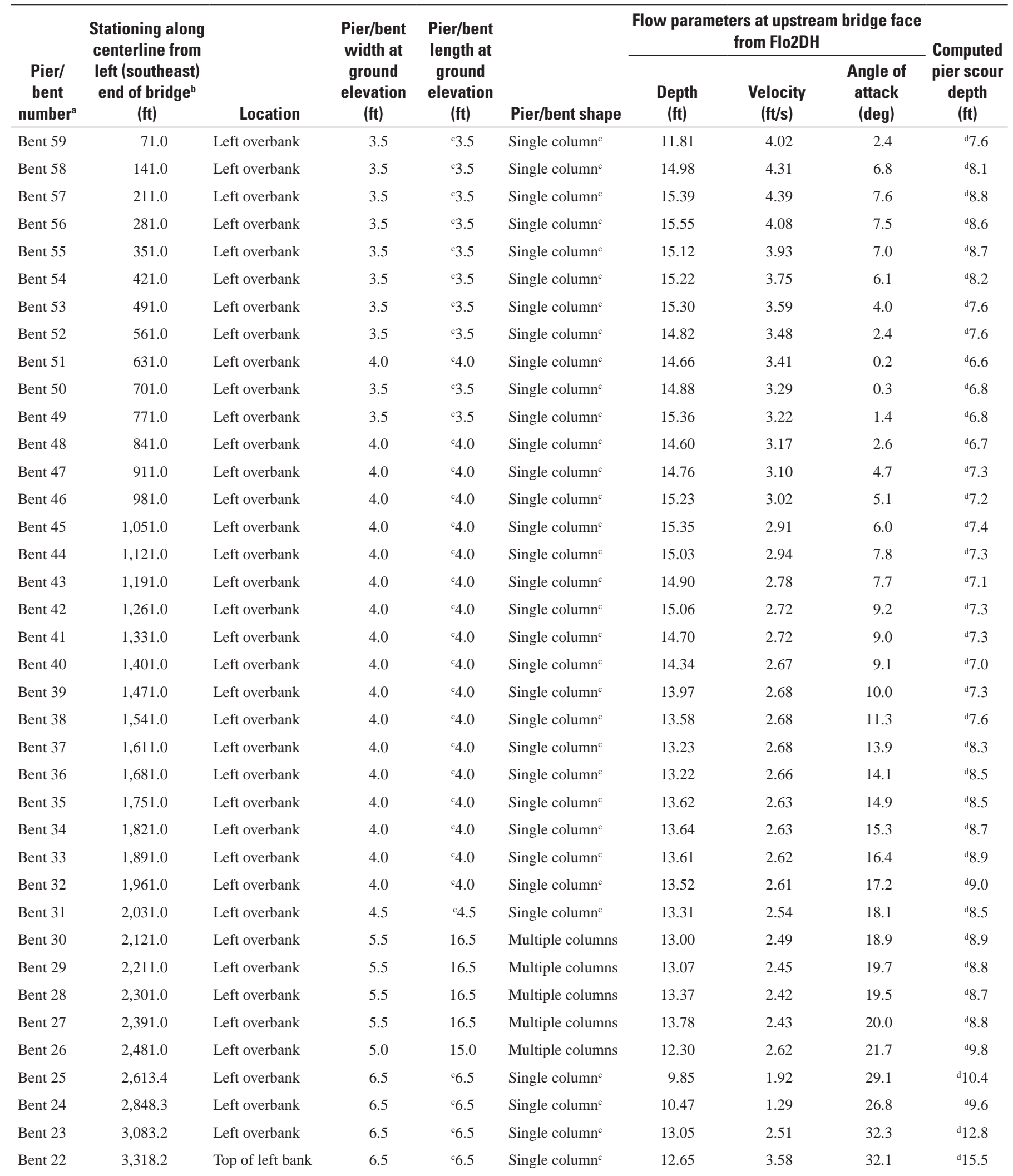


Table 7. Predicted local pier scour depths and parameters used to compute pier scour for the project design flood on the Mississippi River near Caruthersville, Missouri.-Continued

[ft, feet; ft/s, feet per second; deg, degrees]

\begin{tabular}{|c|c|c|c|c|c|c|c|c|c|}
\hline \multirow{2}{*}{$\begin{array}{l}\text { Pier/ } \\
\text { bent } \\
\text { number }\end{array}$} & \multirow{2}{*}{$\begin{array}{l}\text { Stationing along } \\
\text { centerline from } \\
\text { left (southeast) } \\
\text { end of bridge } \\
\text { (ft) }\end{array}$} & \multirow[b]{2}{*}{ Location } & \multirow{2}{*}{$\begin{array}{l}\text { Pier/bent } \\
\text { width at } \\
\text { ground } \\
\text { elevation } \\
\text { (ft) }\end{array}$} & \multirow{2}{*}{$\begin{array}{l}\text { Pier/bent } \\
\text { length at } \\
\text { ground } \\
\text { elevation } \\
\text { (ft) }\end{array}$} & \multirow[b]{2}{*}{ Pier/bent shape } & \multicolumn{3}{|c|}{$\begin{array}{c}\text { Flow parameters at upstream bridge face } \\
\text { from Flo2DH }\end{array}$} & \multirow{2}{*}{$\begin{array}{l}\text { Computed } \\
\text { pier scour } \\
\text { depth } \\
\text { (ft) }\end{array}$} \\
\hline & & & & & & $\begin{array}{c}\text { Depth } \\
\text { (ft) }\end{array}$ & $\begin{array}{l}\text { Velocity } \\
\text { (ft/s) }\end{array}$ & $\begin{array}{l}\text { Angle of } \\
\text { attack } \\
\text { (deg) }\end{array}$ & \\
\hline Pier 21 & $3,556.1$ & Left bank & 17.0 & 100.5 & Round-nosed & 41.92 & 5.54 & 9.1 & 34.7 \\
\hline Pier 20 & $4,476.0$ & Main channel & 21.0 & 104.5 & Round-nosed & e99.00 & ${ }^{\mathrm{e}} 10.82$ & 2.4 & $\mathrm{~d} 73.6$ \\
\hline Pier 18 & $5,233.8$ & Main channel & 7.5 & 53.5 & Round-nosed & e99.00 & ${ }^{\mathrm{e}} 10.82$ & 1.1 & d 56.7 \\
\hline Pier 17 & $5,468.8$ & Main channel & 7.5 & 53.5 & Round-nosed & e99.00 & ${ }^{\mathrm{e}} 10.82$ & 3.6 & $\mathrm{~d} 33.1$ \\
\hline Pier 16 & $5,703.7$ & Main channel & 7.5 & 53.5 & Round-nosed & e99.00 & ${ }^{\mathrm{e}} 10.82$ & 4.7 & $\mathrm{~d} 35.4$ \\
\hline Pier 15 & $5,938.6$ & Right bank & 7.5 & 53.5 & Round-nosed & 58.44 & 6.45 & 4.7 & $\mathrm{~d} 40.9$ \\
\hline Bent 11 & $6,341.0$ & Right overbank & 6.0 & 18.0 & Multiple columns & 18.76 & 1.37 & 49.0 & 11.4 \\
\hline Bent 10 & $6,431.0$ & Right overbank & 6.0 & 18.0 & Multiple columns & 19.91 & 1.44 & 40.4 & 11.2 \\
\hline Bent 9 & $6,521.0$ & Right overbank & 6.0 & 18.0 & Multiple columns & 19.04 & 1.44 & 32.5 & 10.5 \\
\hline Bent 8 & $6,611.0$ & Right overbank & 5.5 & 16.5 & Multiple columns & 19.07 & 1.53 & 27.0 & 9.6 \\
\hline Bent 7 & $6,681.0$ & Right overbank & 5.0 & 15.0 & Multiple columns & 19.85 & 1.64 & 20.9 & 8.7 \\
\hline Bent 6 & $6,751.0$ & Right overbank & 5.0 & 15.0 & Multiple columns & 20.45 & 1.79 & 16.3 & 8.4 \\
\hline Bent 5 & $6,821.0$ & Right overbank & 5.0 & 15.0 & Multiple columns & 20.96 & 1.80 & 10.8 & 7.7 \\
\hline Bent 4 & $6,891.0$ & Right overbank & 5.0 & 15.0 & Multiple columns & 21.31 & 1.99 & 4.3 & 6.8 \\
\hline Bent 3 & $6,961.0$ & Right overbank & 4.5 & ${ }^{\prime} 4.5$ & Single column ${ }^{c}$ & 21.75 & 1.97 & 1.6 & ${ }^{\circ} 6.8$ \\
\hline
\end{tabular}

aPier/bent number corresponds to bridge plans from Missouri Department of Transportation (1974).

${ }^{b}$ Stationing is the distance from the left abutment fill face (as viewed facing downstream).

"Pier/bent length at ground elevation" and "Pier/bent shape" are for a single column of a multiple column bent because the spacing between the columns is greater than 5 times the column diameter. The computed pier scour depth at this bent is 1.2 times the local scour of a single column, based on guidelines in Hydraulic Engineering Circular No. 18 (Richardson and Davis, 2001), except for those with complex pier foundation exposure after contraction scour (footnote d).

${ }^{\mathrm{d}}$ Computed contraction scour depths resulted in footing or pile exposure at this pier or bent. Local pier scour depths were computed using equations for complex pier foundations (Richardson and Davis, 2001).

${ }^{\text {e}}$ The maximum depth and velocity in the main channel were used to compute pier scour depth to account for the possibility of a shift in the channel thalweg. 

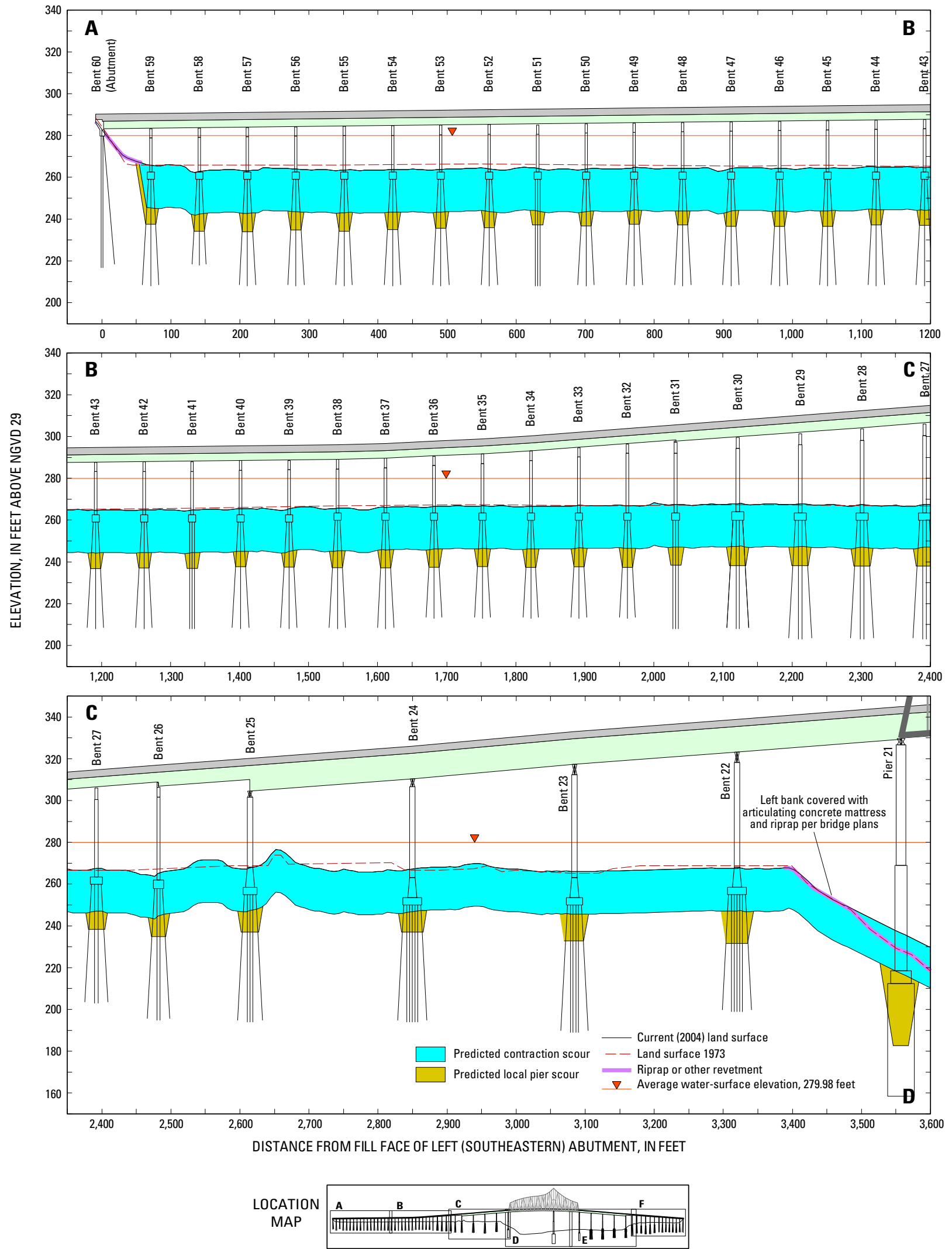

Figure 13. Predicted contraction and local pier scour depths under the Tennessee-approach (left overbank) spans for the project design flood on the Mississippi River near Caruthersville, Missouri. 


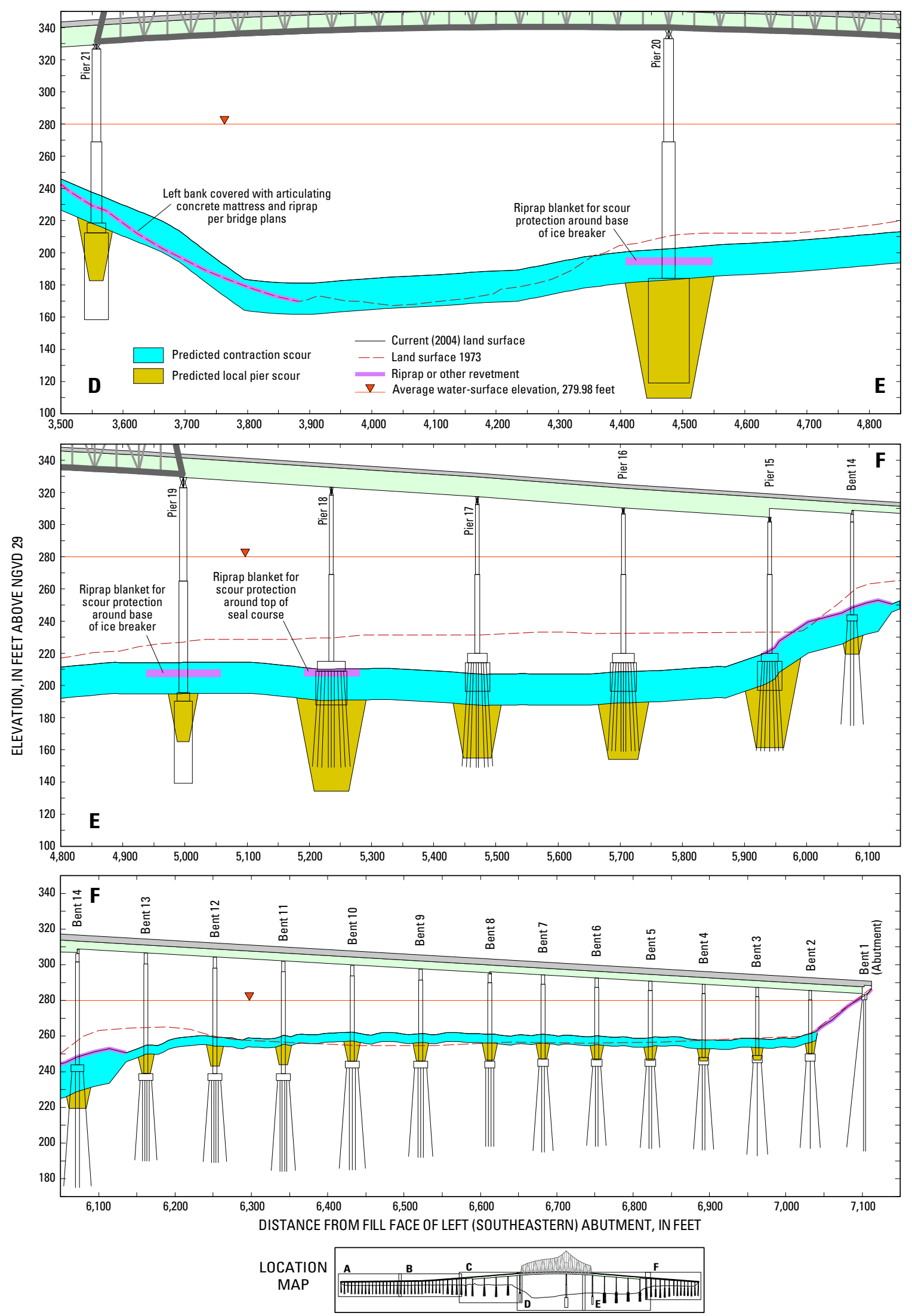

Figure 14. Predicted contraction and local pier scour depths under the main-channel and Missouri-approach (right overbank) spans for the project design flood on the Mississippi River near Caruthersville, Missouri. 

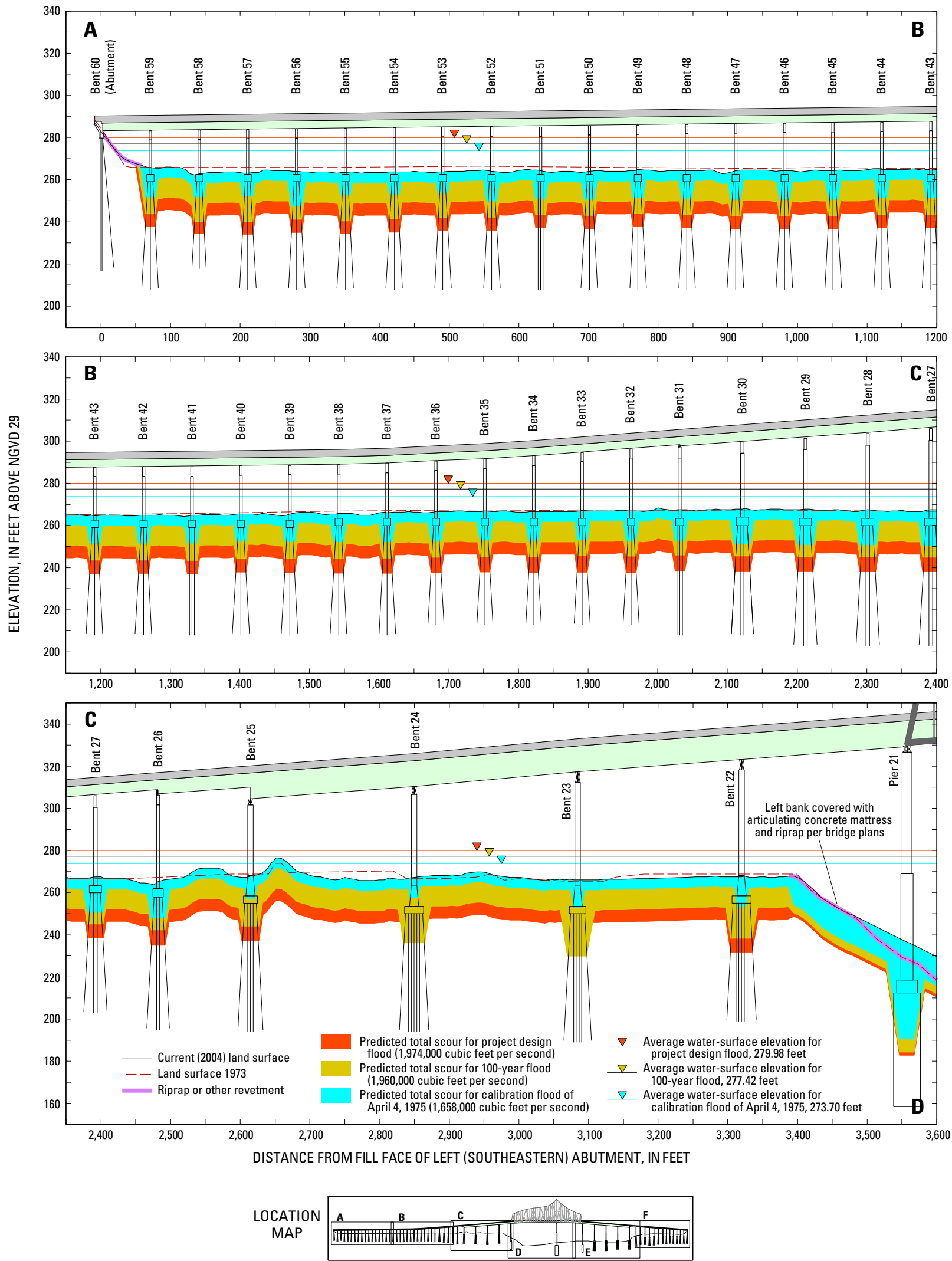

Figure 15. Predicted total scour depths under the Tennessee-approach (left overbank) spans for three floods on the Mississippi River near Caruthersville, Missouri. 


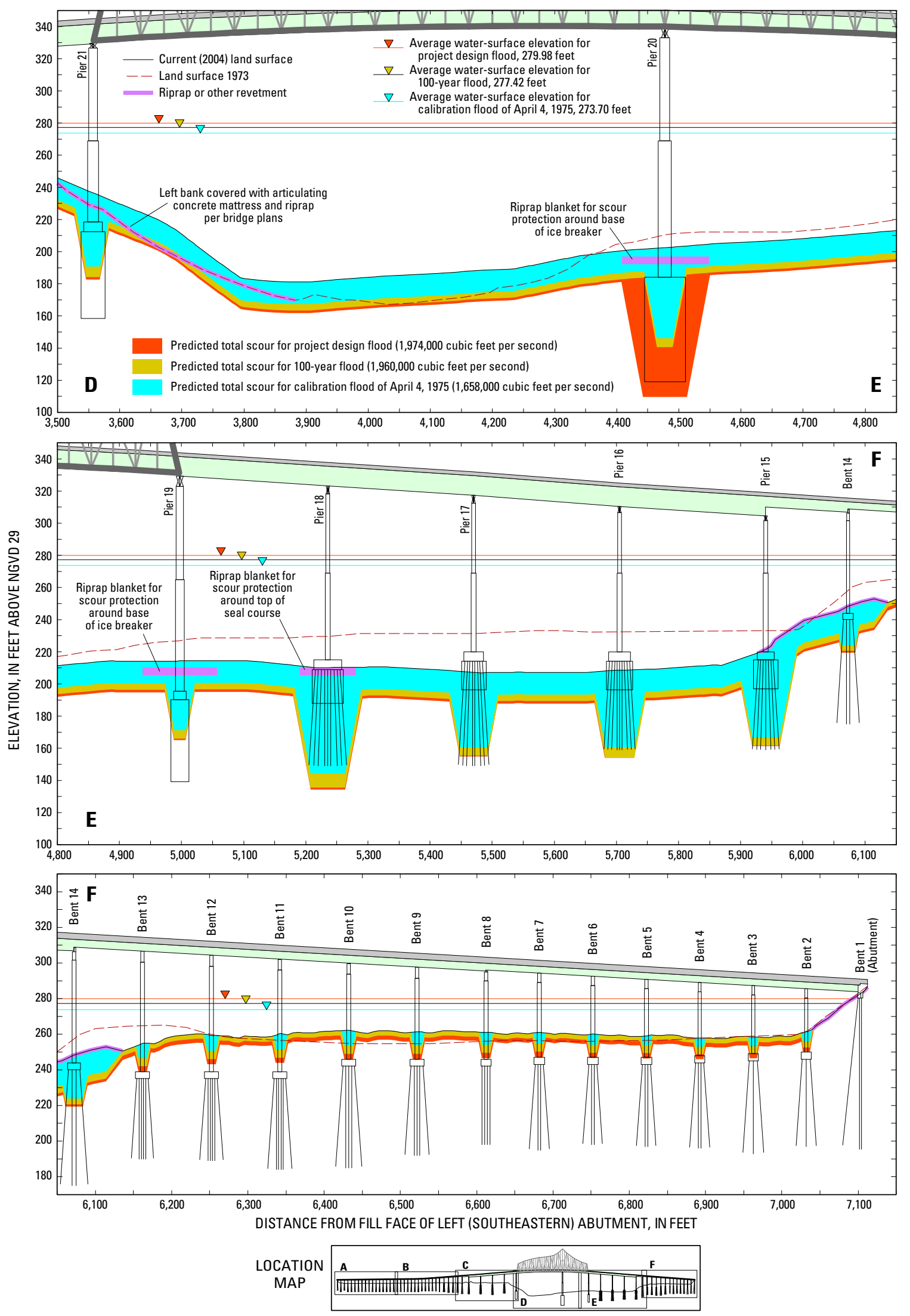

Figure 16. Predicted total scour depths under the main-channel and Missouri-approach (right overbank) spans for three floods on the Mississippi River near Caruthersville, Missouri. 
bents on the right overbank are not substantially exposed in any of the flood simulations.

Abutment scour depths were computed for the three simulations (table 8) using the Highways in the River Environment (HIRE) scour equation (Richardson and Davis, 2001). The abutment scour depths assume no protection on the abutment faces; however, guidebanks upstream from both abutments (fig. 6) likely will move the abutment scour hole away from the bridge substructure (Melville and Coleman, 2000), and the abutment and upstream guidebanks are covered with large riprap boulders and stone revetment (fig. 17), which likely will provide resistance to abutment scour. Therefore, no abutment scour is shown on figures 13 through 16 .

Resistance to contraction and local pier scour may be provided by revetment features around structure A-1700. Based on bridge plans (Missouri Department of Transportation, 1974) and visual observations, revetment in the form of riprap blankets and an articulated concrete mattress are present around the main-channel piers (piers 18 through 21 ), on the left and upper right banks, and on abutments and guidebank faces (fig. 4 and figs. 13-16). These revetment features likely will limit the amount of scour that occurs at these locations; however, no revetment is present near the main-channel piers 16 and 17, and the total scour depths indicate these piers are substantially exposed or undermined in all three flood simulations. Riprap in the vicinity of pier 15 is inferred from visual observation of riprap on the upper right bank around bent 14 , but pier 15 also was substantially exposed or undermined in the three flood simulations in the absence of scour protection.

Additional resistance to local pier scour may be provided by the structure of the piers and bents. According to Richardson and Davis (2001), when the computed contraction scour depth does not cause exposure of the top of the footing at a pier or bent (such that the footing is not exposed to flow after contraction scour), the wider footing may arrest local pier scour. This may limit the local pier scour for several of the main-channel piers and the bents on the right overbank. For the bents on the right overbank, the computed contraction scour depths did not cause the exposure of any of the footings (figs. 14 and 16); therefore, the local pier scour at these bents may be limited to the tops of the footings. For the piers in the main channel, the tops of the pedestals or caissons at piers 19 through 21 have no or limited exposure from the computed contraction scour depths for the three simulated floods (figs. 14 and 16); therefore, the local pier scour may be limited to the tops of the pedestals or caissons at these piers. This additional resistance to pier scour would not apply to piers 16,17 , and 18 because the footings and seal courses of these piers already were exposed to flow by the current (2004) land surface (figs. 4, 14 and 16).

Finally, the predicted contraction scour depths are based on the assumption of an infinite depth of erosive material and a homogeneous particle-size distribution; however, USACE and MoDOT bore logs indicate that the material on the flood plain changes with increased depth from sandy silt to sand.

Table 8. Predicted abutment scour depths and parameters used to compute abutment scour on the Mississippi River near Caruthersville, Missouri.

[ft $\mathrm{ft}^{3} \mathrm{~s}$, cubic feet per second; $\mathrm{ft}^{2}$, square feet; $\mathrm{ft}$, feet; deg, degrees; $\mathrm{ft} / \mathrm{s}$, feet per second]

\begin{tabular}{|c|c|c|c|}
\hline \multirow[b]{2}{*}{ Parameter required to compute scour depth } & \multicolumn{3}{|c|}{ Flood } \\
\hline & Calibration & 100-year & Project design \\
\hline Flood discharge $\left(\mathrm{ft}^{3} / \mathrm{s}\right)$ & $1,658,000$ & $1,960,000$ & $1,974,000$ \\
\hline Discharge blocked by embankment $\left(\mathrm{ft}^{3} / \mathrm{s}\right)$ & 24,000 & 51,600 & 66,800 \\
\hline Area of blocked flow $\left(\mathrm{ft}^{2}\right)$ & 52,400 & 73,000 & 85,600 \\
\hline Embankment skew (deg) ${ }^{\mathrm{a}}$ & 15 & 15 & 15 \\
\hline Velocity at embankment toe near upstream edge of bridge (ft/s) & 2.29 & 3.68 & 4.09 \\
\hline Computed abutment scour depth (ft) & 14.3 & 24.1 & 30.0 \\
\hline \multicolumn{4}{|c|}{ Right embankment blocked section (fig. 12) } \\
\hline Embankment skew $(\mathrm{deg})^{\mathrm{a}}$ & -40 & -40 & -40 \\
\hline Velocity at embankment toe near upstream edge of bridge (ft/s) & 1.44 & 2.20 & 2.52 \\
\hline Computed contraction scour depth (ft) & 23.6 & 32.3 & 37.4 \\
\hline
\end{tabular}

${ }^{\mathrm{a}} \mathrm{A}$ negative value for skew indicates the embankment points downstream. 


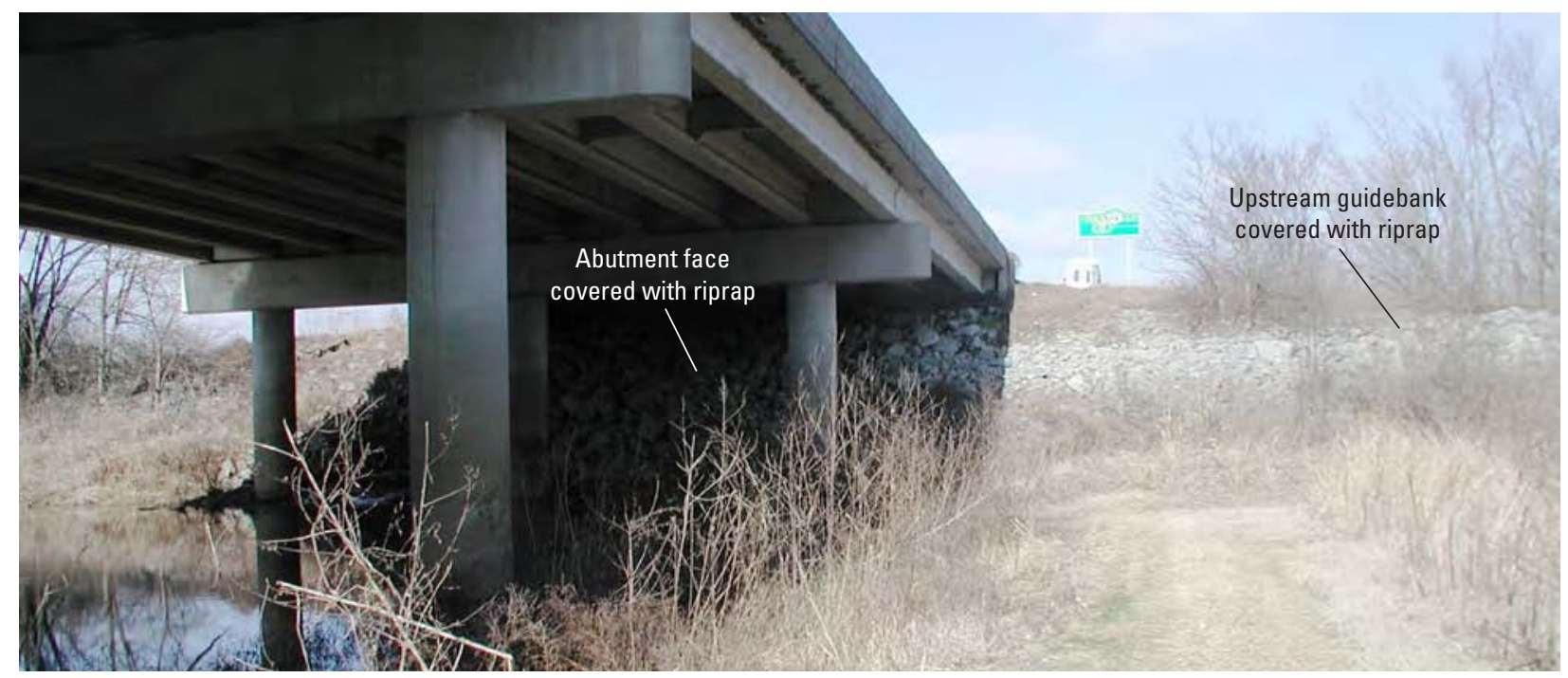

Figure 17. Abutment and part of the guidebank upstream from the right (northwest) end of structure A-1700 over the Mississippi River near Caruthersville, Missouri, January 23, 2007.

Assuming the material on the left overbank was a fine to medium sand $\left(\mathrm{D}_{50}=0.40 \mathrm{~mm}\right)$ and using identical hydraulic parameters from the PDF simulation to compute the contraction scour on the left overbank, the predicted overbank contraction scour depth is only $3.9 \mathrm{ft}$ as compared to the predicted depth of $20.6 \mathrm{ft}$ for sandy silt $\left(\mathrm{D}_{50}=0.04 \mathrm{~mm}\right)$; therefore, the contraction scour depths may not reach the predicted values because of the non-homogeneous nature of the material, particularly on the overbanks.

\section{Summary}

A two-dimensional hydrodynamic flow model was used to simulate flow conditions on the Mississippi River in the vicinity of structure A-1700, the Interstate 155 crossing of the river near Caruthersville, Missouri. The model was used to simulate flow conditions for three discharges: a flood that occurred on April 4, 1975 (the calibration flood), the 100year flood, and the project design flood. The project design flood was essentially equivalent to the flood that would cause impending overtopping of the mainline levees along the Mississippi River in the vicinity of structure A-1700. Discharge and river-stage readings from the flood of April 4, 1975, were used to calibrate the flow model. The model was then used to simulate the 100-year and project design floods.

The flow conditions simulated in the model were used to estimate the contraction, local pier, and abutment scour depths for the three discharges. The predicted contraction scour depths for the calibration flood were 13.8 and 5.0 feet for main channel and left overbank (as viewed facing downstream), respectively; a value of 0 feet was predicted for the contraction scour depth on the right overbank for the calibration flood. The predicted main-channel contraction scour depth for the 100-year flood was 17.7 feet, with predicted overbank contraction scour depths of 14.4 and 2.6 feet for the left and right overbanks, respectively. The predicted main-channel contraction scour depth for the project design flood was 19.4 feet, with predicted overbank contraction scour depths of 20.6 and 5.2 feet for the left and right overbanks, respectively.

Predicted total scour depths (contraction and local pier scour) for the calibration flood were the least, whereas the predicted total scour depths for the project design flood generally were the greatest. The maximum predicted total scour depth (contraction and local pier scour) for the calibration flood was 66.1 feet, occurring at pier 18 . The maximum predicted total scour depth for the 100-year flood was 74.6 feet, also occurring at pier 18. The maximum predicted total scour depth for the project design flood was 93.0 feet, occurring at pier 20 . The footings of the bents on the left overbank are undermined and the piles are moderately to substantially exposed in all three of the discharge simulations. The bents on the right overbank are minimally exposed in the three discharge simulations. Piers 15 through 21 in the main channel and bent 14 on the right bank would be substantially exposed or undermined by the predicted total scour depths in all three of the discharge simulations in the absence of scour protection. Piers 18 through 21 have scour protection in the form of a riprap blanket around the base of each according to bridge plans, and the riprap blanket observed on the right bank around bent 14 is believed to extend around the base of pier 15; this revetment likely would limit the amount of scour that would occur at these piers. Furthermore, the footings and caissons that are not exposed by predicted contraction scour may arrest local pier scour, which may limit local pier scour at several bents and piers. Abutment scour depths were computed for structure A-1700, but are expected to be mitigated by the presence of guidebanks upstream from the abutments, as well as riprap revetment on the abutment and guidebank faces. 


\section{References Cited}

Arcement, G.J., Jr., and Schneider, V.R., 1989, Guide for selecting Manning's roughness coefficients for natural channels and flood plains: U.S. Geological Survey Water-Supply Paper 2339, 38 p.

Barnes, H.H., Jr., 1967, Roughness characteristics on natural channels: U.S. Geological Survey Water-Supply Paper 1849,213 p.

Chow, V.T., 1959, Open-channel hydraulics: St. Louis, Mo., McGraw-Hill Publishing Company, 678 p.

Environmental Modeling Research Laboratory, 1999, Surfacewater modeling system reference manual, version 8.0: Provo, Utah, Brigham Young University, 315 p.

Froehlich, D.C., 2002, Two-dimensional depth-averaged flow and sediment transport model-Users manual for FESWMS Flo2DH: Federal Highway Administration, FHWA-RD03-053, $203 \mathrm{p}$.

Huizinga, R.J., 2007, Two-dimensional hydrodynamic modeling and analysis of the proposed channel modifications and grade control structure on the Blue River near Byram's Ford Industrial Park, Kansas City, Missouri: U.S. Geological Survey Scientific Investigations Report 2007-5098, 45 p.

Huizinga, R.J., and Rydlund, P.H., Jr., 2001, Simulation of flow and evaluation of bridge scour at Horse Island Chute Bridge near Chester, Illinois: U.S. Geological Survey WaterResources Investigations Report 01-4176, 28 p.

Huizinga, R.J., and Rydlund, P.H., Jr., 2004, Potential-scour assessments and estimates of scour depth using different techniques at selected bridge sites in Missouri: U.S. Geological Survey Scientific Investigations Report 2004-5213, $42 \mathrm{p}$.

Melville, B.W., and Coleman, S.E., 2000, Bridge scour: Highlands Ranch, Colo., Water Resources Publications, 550 p.

Missouri Department of Transportation, 1974, Bridge over Mississippi River near Caruthersville, Missouri: Jefferson City, Missouri State Highway Department, Project Nos. I-155-1(32-35), Bridge No. A-1700.

Richardson, E.V., and Davis, S.R., 2001, Evaluating scour at bridges (4th ed.): U.S. Federal Highway Administration Publication FHWA NHI 01-001 Hydraulic Engineering Circular No. 18, 378 p.

U.S. Army Corps of Engineers, 2007a, River Engineering Branch: Memphis District, U.S. Army Corps of Engineers, accessed May 24, 2007, at http://155.76.117.11/river/ default.htm.
U.S. Army Corps of Engineers, 2007b, Water control home page: Memphis District, U.S. Army Corps of Engineers, accessed May 24, 2007, at http://155.76.117.11/hydraulics/ memphis.htm.

U.S. Federal Highway Administration, 1988, Scour at bridges: Washington, D.C., Federal Highway Administration Technical Advisory 5140.20, 4 p. 
Prepared by:

USGS Enterprise Publishing Network

Rolla Publishing Service Center

1400 Independence Road

Rolla, M0 65401

For more information concerning this publication, contact:

Director

U.S. Geological Survey

Missouri Water Science Center

1400 Independence Road

Rolla, M0 65401

(573) 308-3667

Or visit the Missouri Water Science Center website at:

http://mo.water.usgs.gov 

